


\section{Betekenis van plantparasitaire nematoden voor Nederlands productiegrasland}

Herman de Boer

Dit onderzoek is uitgevoerd door Wageningen Livestock Research en gefinancierd door het Ministerie van Landbouw, Natuur en Voedselkwaliteit, binnen het KennisBasisproject Bodemindicatoren (KB-21-002-010)

Wageningen Livestock Research

Wageningen, december 2018 
De Boer, Herman, 2018. Betekenis van plantparasitaire nematoden voor Nederlands productiegrasland. Wageningen Livestock Research, Rapport 1142

Dit rapport is gratis te downloaden op https://doi.org/10.18174/469022

of op www.wur.nl/livestock-research (onder Wageningen Livestock Research publicaties).

(C) 2018 Wageningen Livestock Research

Postbus 338, 6700 AH Wageningen, T 03174839 53, E info.livestockresearch@wur.nl, www.wur.nl/livestock-research. Wageningen Livestock Research is onderdeel van Wageningen University \& Research.

Wageningen Livestock Research aanvaardt geen aansprakelijkheid voor eventuele schade voortvloeiend uit het gebruik van de resultaten van dit onderzoek of de toepassing van de adviezen.

Alle rechten voorbehouden. Niets uit deze uitgave mag worden vermenigvuldigd en/of openbaar gemaakt worden door middel van druk, fotokopie, microfilm of op welke wijze dan ook zonder voorafgaande toestemming van de uitgever of auteur.

Wageningen Livestock Research is NEN-EN-ISO 9001:2015 gecertificeerd. Op al onze onderzoeksopdrachten zijn de Algemene Voorwaarden van de Animal Sciences Group van toepassing. Deze zijn gedeponeerd bij de Arrondissementsrechtbank Zwolle.

Wageningen Livestock Research Rapport 1142 


\section{Inhoud}

$\begin{array}{ll}\text { Woord vooraf } & 5\end{array}$

$\begin{array}{ll}\text { Samenvatting } & 6\end{array}$

$\begin{array}{ll}\text { Inleiding } & 7\end{array}$

$\begin{array}{llr}2 & \text { Materiaal en methoden } & 8\end{array}$

$3 \quad$ Resultaten en discussie $\quad 9$

3.1 Wat zijn plantparasitaire nematoden? 9

3.1.1 Omschrijving 9

3.1.2 Voedingswijze 9

3.1.3 Voortplanting en overleving 10

3.1.4 Verspreiding 10

3.2 Soorten in grasland $\quad 10$

3.2.1 Regelmatig aangetroffen soorten 10

3.2.2 Invloed van waardplanten 13

3.2.3 Schadelijke soorten 13

3.3 Schademechanismen 14

3.3.1 Zichtbare schadesymptomen 14

3.3.2 Directe schade 14

$\begin{array}{ll}3.3 .3 & \text { Indirecte schade }\end{array}$

3.3.4 Invloed van groeistadium en groeiomstandigheden 16

$\begin{array}{ll}3.3 .5 \text { Schadedrempels } & 17\end{array}$

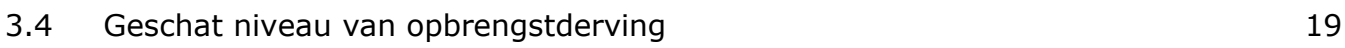

3.4.1 Schattingsmethoden 19

$\begin{array}{ll}3.4 .2 \text { Berekening voedselbehoefte } & 19\end{array}$

$\begin{array}{ll}3.4 .3 \text { Inoculatieproeven } & 19\end{array}$

$\begin{array}{ll}3.4 .4 \text { Ontsmettingsproeven } & 20\end{array}$

3.5 Voordelen van plantparasitaire nematoden 20

3.5.1 Introductie $\quad 20$

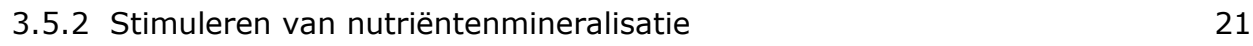

$\begin{array}{ll}3.5 .3 \text { Stimuleren van biodiversiteit } & 21\end{array}$

3.6 Beheersing van plantparasitaire nematoden $\quad 22$

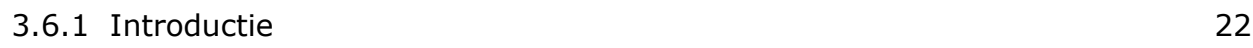

3.6.2 Graslandmanagement $\quad 23$

$\begin{array}{ll}3.6 .3 \text { Organische mest } & 23\end{array}$

$\begin{array}{ll}3.6 .4 \text { Vruchtwisseling } & 23\end{array}$

3.6.5 Chemische bestrijding $\quad 23$

3.6.6 Resistente of tolerante grasrassen $\quad 24$

$4 \quad$ Reflectie \& aanbevelingen $\quad 25$

$\begin{array}{ll}\text { Conclusies } & 26\end{array}$

Dankwoord $\quad 27$

$\begin{array}{lr}\text { Referenties } & 28\end{array}$ 



\section{Woord vooraf}

Bodemgezondheid en bodemweerbaarheid zijn belangrijke thema's voor de Nederlandse landbouw. Bij deze thema's ligt het accent meestal op akkerbouwgewassen en veel minder op grasland, hoewel dit in Nederland een belangrijk gewas is. Bij de bodemgezondheid van grasland is de invloed van plantparasitaire nematoden op de productiviteit een belangrijk onderwerp. Hieraan is de laatste decennia echter weinig aandacht besteed. Daarom is binnen het Kennisbasis(KB)onderzoek van Wageningen UR besloten om dit onderwerp een nieuwe impuls te geven en de kennis op dit gebied te actualiseren. De impuls bestaat uit twee activiteiten: 1) een literatuurstudie naar de betekenis van plantparasitaire nematoden voor Nederlands productiegrasland en 2) een inventarisatie van de soorten en aantallen plantparasitaire nematoden die in Nederlands productiegrasland voorkomen. In dit rapport worden de resultaten van de literatuurstudie beschreven. 


\section{Samenvatting}

Het effect van bodemgebonden ziekten en plagen op de opbrengst en kwaliteit van productiegrasland is in Nederland relatief onderbelicht. Een onderbelichte groep plaagorganismen zijn plantparasitaire nematoden (PPN). Dit zijn herbivore nematoden, kleine rondwormen die zich voeden aan plantenwortels en daardoor economische schade aan gewassen kunnen veroorzaken. In Nederland is na 1980 het onderzoek aan PPN in productiegrasland sterk afgenomen. Ondertussen zijn er in de laatste decennia grote veranderingen in het graslandmanagement geweest. Deze veranderingen hebben gevolgen voor de diversiteit en aantallen van PPN en de schade die ze veroorzaken. Het is daarom van belang geworden om te inventariseren wat de belangrijkste effecten van PPN zijn op het functioneren van Nederlands productiegrasland. Hiervoor is een literatuurstudie uitgevoerd. De resultaten daarvan worden beschreven in dit rapport.

Plantparasitaire nematoden veroorzaken directe schade aan grasland door het aanboren en leegzuigen van wortelcellen, het binnendringen van de wortels, en door lekkage van sap uit de beschadigde cellen. Beschadiging van wortelcellen geeft gevolgschade door beschadiging van het wortelstelsel en een grotere gevoeligheid van de wortels voor droogte, nutriëntengebrek en aantasting door andere pathogenen. Gras is bijzonder gevoelig voor schade tijdens de kiemplantfase, omdat de kiemplantjes dan de enige voedselbron zijn voor de relatief grote populatie nematoden. Hierdoor kunnen veel kiemplantjes afsterven en kan de inzaai volledig mislukken. Bij bestaand grasland is schade (in de vorm van opbrengstderving) voor een belangrijk deel het gevolg van stress van het wortelstelsel. Deze stress wordt veroorzaakt door verslechtering van de groeiomstandigheden, bijvoorbeeld door een vochttekort, een nutriëntentekort, verzuring, vernatting en verdichting. Mede daardoor is schade door PPN afhankelijk van het groeistadium en de groeiomstandigheden van het gras; dezelfde aantallen PPN kunnen in de ene situatie (vochttekort) wel opbrengstderving geven en in een andere situatie (ruime vochtvoorziening) niet. Hierdoor zijn betrouwbare schadedrempels voor PPN moeilijk vast te stellen. Het niveau van opbrengstderving als gevolg van aantasting door PPN kan met drie methoden vastgesteld worden: door berekening van de voedselbehoefte van PPN, door inoculatie van de grond met PPN, of door ontsmetting van de grond. Van deze methoden lijkt ontsmetting de meest betrouwbare. Op basis van ontsmettingsproeven (periode 1950 tot 1980) kan de historische opbrengstderving geschat worden op jaarlijks gemiddeld 1,2 ton DS ha-1 of $13 \%$ van de opbrengst. Op individuele percelen kon in het verleden bij verhoogde dichtheden van PPN de derving oplopen tot $53 \%$. De gemiddelde opbrengstderving komt overeen met een economische schade van jaarlijks $€ 200$ miljoen en kan mogelijk een deel van de 'yield gap' van grasland verklaren. Door veranderingen in graslandmanagement is deze gemiddelde opbrengstderving waarschijnlijk niet meer actueel. Nieuw schadeonderzoek is daarom nodig.

Plantparasitaire nematoden hebben ook positieve effecten; ze kunnen de mineralisatie van nutriënten in de bodem stimuleren en de diversiteit van plantensoorten in de graszode bevorderen. Voor Nederlands productiegrasland wegen de voordelen van PPN echter niet op tegen de nadelen en daarom is het gewenst om de aantallen PPN in productiegrasland laag te houden. De (relatieve) schade door PPN kan verminderd worden door zorgvuldig graslandmanagement en te hoge aantallen PPN kunnen teruggedrongen worden door regelmatige organische bemesting of vruchtwisseling.

Het is niet bekend welke soorten PPN in welke aantallen momenteel in productiegrasland aanwezig zijn. Daardoor is ook niet duidelijk welke soort(en) het meest kunnen bijdragen aan de opbrengstderving. Om dit inzicht te verkrijgen is een nationale kartering van herbivore nematoden in productiegrasland nodig. Een dergelijke kartering geeft ook inzicht in de bijdrage van herbivore nematoden aan de biodiversiteit. 


\section{$1 \quad$ Inleiding}

Het effect van bodemgebonden ziekten en plagen op de opbrengst en kwaliteit van productiegrasland is in Nederland relatief onderbelicht. Bekend is dat onder andere insectenlarven (emelten, ritnaalden, engerlingen), schimmels (roest, meeldauw) en plantparasitaire nematoden schade kunnen veroorzaken. Aan deze ziekten en plagen wordt echter weinig aandacht besteed en er wordt weinig onderzoek naar verricht, zeker vergeleken met akkerbouwgewassen. Redenen daarvoor zijn dat, vergeleken met akkerbouwgewassen, de economische waarde van grasland relatief laag is, de weerbaarheid van grasland hoger wordt ingeschat en de schade in grasland minder duidelijk zichtbaar is. Grasland is echter wel een belangrijk gewas in Nederland en het is met een areaal van 680.000 ha blijvend grasland en 248.000 ha tijdelijk grasland (CBS 2018) het meest geteelde gewas.

Een onderbelichte groep plaagorganismen, waarvan niet duidelijk is hoeveel schade ze momenteel in grasland aanrichten, zijn plantparasitaire nematoden (PPN). Dit zijn herbivore nematoden, kleine rondwormen die op en in de wortels leven en zich daarop voeden, en waarvan aangetoond is of verwacht wordt dat ze economische schade aan gewassen veroorzaken. Kort na de Tweede Wereldoorlog werd in Nederland aan dit type nematoden relatief veel onderzoek verricht door de afdeling Nematologie van de Plantenziektekundige Dienst (Wageningen), onder leiding van prof. Michiel Oostenbrink. Aanleiding daarvoor was de toen recente (her)ontdekking van schade door vrijlevende nematoden in de VS (Oostenbrink 1954, 1957b). Tot eind jaren zeventig is er in Nederland regelmatig (veld)onderzoek verricht naar schade door PPN in productiegrasland. Daarna is dit sterk afgenomen. Ondertussen zijn er in de laatste decennia, door schaalvergroting en intensivering van de melkveehouderij, grote veranderingen geweest in het graslandmanagement. Deze veranderingen bestaan uit onder meer uit toegenomen ruilverkaveling, verbeterde ontwatering en afwatering, een hogere frequentie van herinzaai, meer monocultuur van Engels raaigras, veranderingen in bemesting, gebruik van zwaardere machines en een afname van beweiden ten gunste van maaien. Dergelijke veranderingen hebben niet alleen effect gehad op de botanische samenstelling en productiviteit van grasland, maar (daarmee) ook op de diversiteit en aantallen van PPN, en op de mogelijke schade die ze veroorzaken.

Door de geschetste veranderingen is het in toenemende mate van belang geworden om, op basis van de huidige stand van het onderzoek, te inventariseren wat de belangrijkste effecten van PPN zijn op het functioneren van Nederlands productiegrasland. Hiervoor is een literatuurstudie uitgevoerd. De resultaten daarvan worden beschreven in dit rapport. 


\section{Materiaal en methoden}

De literatuurstudie is uitgevoerd door op relevante termen te zoeken in de multidisciplinaire zoekmachine 'Web of Science' en in de online catalogus van de bibliotheek van Wageningen UR. Daarnaast zijn regelmatig referenties uit de literatuurlijsten van publicaties gecheckt en is soms ook gebruik gemaakt van literatuur die niet openbaar toegankelijk is (bv. een aantal jaarverslagen van de Plantenziektekundige Dienst). De toegang tot relevante literatuur en verdere relevante informatie is uitgebreid door contacten met een aantal nematologen en bodembiologen (zie ook het Dankwoord).

Bij de literatuurstudie zijn enkele vragen als leidraad gebruikt, waaronder: welke soorten nematoden komen voor en in welke aantallen? Welke soorten veroorzaken schade, hoe veroorzaken ze schade, onder welke omstandigheden, en is deze schade relevant? Hebben parasitaire nematoden ook positieve effecten? En in hoeverre kunnen positieve effecten de negatieve effecten compenseren? Kunnen parasitaire nematoden ook bestreden worden? Bij de nu volgende rapportage van de resultaten wordt eerst een algemeen beschrijvend hoofdstuk gegeven en daarna antwoorden op de geformuleerde vragen. 


\section{Resultaten en discussie}

\subsection{Wat zijn plantparasitaire nematoden?}

\subsubsection{Omschrijving}

Plantparasitaire nematoden (PPN) zijn herbivore nematoden (aaltjes), kleine (rond)wormen die op en in de plant leven en zich daaraan voeden. Herbivore nematoden onderscheiden zich daarmee van nematoden die zich voeden met dood organisch materiaal (saprofytische nematoden), bacteriën (bacterivore nematoden), schimmels (fungivore nematoden), met meerdere voedselbronnen (omnivore nematoden) of met andere bodemorganismen (carnivore nematoden). Onder de herbivore nematoden zijn er soorten die op en in de wortels leven (wortelaaltjes), alsook soorten die op en in de stengels of bladeren leven (stengelaaltjes en bladaaltjes). In deze studie ligt de focus op wortelaaltjes.

Herbivore nematoden hebben meestal zeer geringe afmetingen, met een lengte variërend van minder dan 0,2 mm (geslacht Paratylenchus) tot meer dan $12 \mathrm{~mm}$ (geslacht Longidorus) (Bridge en Williams 2002). Afgezien van de voortplantingsorganen is er weinig verschil te zien tussen mannelijke en vrouwelijke nematoden, behalve bij de geslachten waar de vrouwtjes in verhouding groot worden en opzwellen, zoals bij de wortelknobbelnematoden (geslacht Meloidogyne) en de cystevormende nematoden (bv. de geslachten Heterodera, Punctodera en Globodera). Veel geslachten van herbivore nematoden staan bekend als plaagdieren van gewassen, omdat ze door hun wijze van voeden en/of voortplanting relatief veel schade aan een gewas kunnen veroorzaken. Geslachten of soorten waarvan aangetoond is dat ze economische schade kunnen veroorzaken worden 'plantparasitair' genoemd. Het onderscheid is niet altijd duidelijk te maken, omdat niet altijd duidelijk is of en wanneer een soort zich parasitair gedraagt en er ook in het onderzoeksgebied niet altijd eenduidig over gedacht wordt.

In het voorliggende rapport wordt regelmatig gebruik gemaakt van de indeling in families, geslachten (binnen families), en soorten (binnen geslachten). Een voorbeeld hiervan: Tylenchorhynchus dubius is een soort van het geslacht Tylenchorhynchus, en Tylenchorhynchus is een geslacht binnen de familie Dolichodoridae.

\subsubsection{Voedingswijze}

Alle bekende herbivore nematoden hebben een intrekbare stekel of speer (Bridge en Williams 2002). Deze stekel wordt gebruikt om de wand van wortelcellen te doorboren en de inhoud op te zuigen. Vertering van het celsap kan deels buiten het lichaam plaatsvinden als er speeksel wordt uitgescheiden. Dit speeksel kan ook een giftig of groeiveranderend effect op wortelcellen en wortelweefsels hebben. Bij het geslacht Meloidogyne leidt celvergroting (hypertrofie) en toename van het aantal wortelcellen (hyperplasie) tot de vorming van wortelknobbels, waarin de nematoden zich ontwikkelen. Herbivore nematoden kunnen verschillende parasitaire gewoonten hebben, afhankelijk van of ze de wortelcellen wel of niet binnendringen en of ze vrij in de bodem leven of in de wortels immobiel worden. Yeates et al. (1993) geven voor PPN de volgende, algemeen gebruikte indeling naar voedingswijze (met een bijbehorende code):

- Sedentaire endoparasieten (1a): onvolwassen vrouwtjes of jonge nematoden dringen de wortels binnen, ontwikkelen een vaste voedingsplek, worden immobiel en zwellen op;

- Vrijlevende endoparasieten (1b): alle levensfasen van de nematoden kunnen het wortelweefsel volledig doordringen, waarbij ze mobiel en wormvormig blijven en zich voeden terwijl ze zich door het weefsel voortbewegen. Vrijlevende endoparasieten migreren vaak tussen de wortels en bodem;

- Semi-endoparasieten (1c): onvolwassen vrouwtjes of jonge nematoden dringen de wortels voor een deel binnen, waarbij de helft of tweederde van hun achterlijf buiten blijft. De nematoden worden immobiel op deze plek en het achterlijf zwelt op;

- Ectoparasieten (1d): de nematoden blijven op het worteloppervlak en voeden zich door hun stekel in te brengen in de wortelcellen die ze kunnen bereiken. 
Daarnaast is er ook een groep herbivore nematoden die zich voedt aan epidermiscellen en wortelharen (1e, Yeates et al. 1993), maar die gezien hun oppervlakkige voedingswijze niet als schadelijk wordt gezien en meestal niet tot de PPN worden gerekend.

\subsubsection{Voortplanting en overleving}

Herbivore nematoden doorlopen vanaf het ei tot volwassenheid vier juveniele, vervellende stadia (Bridge en Williams 2002). De eieren worden in de bodem en/of het wortelweefsel gelegd of blijven aanwezig in het achterlijf van dode vrouwtjes, zoals bij de sedentaire endoparasieten van het geslacht Heterodera. De levenscyclus van nematoden is meestal korter bij hogere temperatuur. Er zijn soorten met één cyclus per jaar of met meerdere cycli. Sommige soorten kunnen zich snel voortplanten en daarmee snel in aantal uitbreiden. Een vrouwtje van het geslacht Meloidogyne kan gemiddeld 200 tot 500 levensvatbare eieren produceren, soms oplopend tot 2000 (Bridge en Williams 2002). Het aardappelcysteaaltje Globodera rostochiensis kan 80-voudig toenemen in een onbehandeld aardappelveld en het stengelaaltje Ditylenchus dipsaci kan 50-voudig toenemen door de teelt van haver (Bridge en Williams 2002).

Nematoden zijn afhankelijk van een waterfilm om te kunnen leven en worden inactief of sterven wanneer deze waterfilm verdwijnt. Sommige soorten gaan in een rustfase wanneer de bodem uitdroogt of de temperatuur daalt en kunnen zo lange tijd overleven. Bij de meeste soorten is het ei, al dan niet beschermd door een cyste (dode achterlijf van het vrouwtje), de toestand waarin ongunstige omstandigheden het beste worden overleefd.

\subsubsection{Verspreiding}

De dichtheid van nematoden in de grond varieert zowel verticaal als horizontaal. Verspreiding van nematoden over grotere afstanden, zowel binnen als tussen percelen, vindt vooral plaats via verspreiding van grond, door bijvoorbeeld wind, water of machines (Kuiper 1977) en nauwelijks door migratie in de grond. Er zijn echter enkele families waarvan de nematoden zich makkelijker en over grotere afstanden door de grond kunnen bewegen. Nematoden van de familie Trichodoridae (o.a. geslachten Paratrichodorus en Trichodorus) kunnen zich actief tot onderin de bouwvoor bewegen (Hijink en Kuiper 1966) en daarmee droogte in de toplaag ontlopen. Deze soorten verplaatsen zich echter niet meer dan 2 meter horizontaal in een seizoen.

\subsection{Soorten in grasland}

\subsubsection{Regelmatig aangetroffen soorten}

Cook en Yeates (1993) geven een overzicht van de soorten PPN die wereldwijd regelmatig in productiegrasland worden aangetroffen. In grasland in een gematigd klimaat, waarbij de soortsamenstelling in de graszode wordt gedomineerd door Engels raaigras (Lolium perenne L.), worden vaak cystenematoden (sedentaire endoparasieten) aangetroffen, waaronder Heterodera avenae, $H$. mani, $H$. bifenestra en Punctodera punctata (Tabel 1). Wanneer witte klaver (Trifolium repens L.) in de graszode aanwezig is wordt ook vaak Heterodera trifolii aangetroffen. Omdat dit geen grasparasiet is, wordt deze soort in die context niet verder besproken. Niet-cystevormende sedentaire endoparasitaire nematoden die regelmatig worden aangetroffen zijn van de soort $M$. naasi. Vrijlevende endoparasitaire nematoden die regelmatig worden aangetroffen zijn soorten van het geslacht Pratylenchus (Pratylenchus spp.). Semi-endoparasitaire nematoden die regelmatig worden aangetroffen zijn Helicotylenchus spp. (vaak H. pseudorobustus) en Rotylenchus spp. (vaak $R$. robustus). Een kanttekening hierbij is dat de soort die voorheen werd aangeduid als $R$. robustus vanaf 1 april 1996 wordt aangeduid als $R$. uniformis, en de soort die voorheen werd aangeduid als $R$. fallorobustus vanaf 1 april 1996 wordt aangeduid als R. robustus (Boag en Neilson 1996; Harm Keidel, pers. med.). Vrijlevende ectoparasitaire nematoden die veel in grasland voorkomen zijn Tylenchorhynchus spp. (vaak T. dubius), Paratylenchus spp., Longidorus spp. (vaak L. elongatus), Xiphinema diversicaudatum en Subanguina radicicola. Ditylenchus dipsaci, het stengelaaltje, wordt in het buitenland regelmatig gevonden (Cook et al. 1992; Cook en Yeates 1993; Fleming et al. 2016) 
maar in Nederland zelden gerapporteerd, mogelijk omdat alleen bodembemonstering niet voldoende effectief is om de aanwezigheid vast te stellen (Cook et al. 1992). D. dipsaci wordt in deze studie verder niet meer besproken omdat de focus ligt op PPN die zich voeden aan graswortels. Vrijlevende ectoparasitaire soorten binnen de geslachten Trichodorus en Paratrichodorus (familie Trichodoridae) komen ook regelmatig in grasland voor, maar worden weinig gerapporteerd. Een reden hiervoor is dat vaak onvoldoende diep wordt bemonsterd om voldoende aantallen van deze soorten te verzamelen. Voor soorten binnen de familie Criconematidae geldt dat de gebruikte extractiemethoden vaak niet geschikt zijn om voldoende aantallen te verzamelen (de nematoden zijn sterk geringd en kunnen moeilijk een wattenfilter passeren). Het bovenstaande overzicht van vaak aangetroffen soorten PPN is hieronder als lijst gegeven in Tabel 1, met daarbij referenties naar studies waarin ze werden aangetroffen.

Binnen de groep vrijlevende herbivore nematoden zijn er ook geslachten die vrijwel altijd en in relatief grote aantallen worden aangetroffen, maar die gezien hun weinig beschadigende voedingswijze (aan epidermiscellen en wortelharen) niet als parasitair worden gezien. Dit zijn geslachten binnen de familie Tylenchidae. 


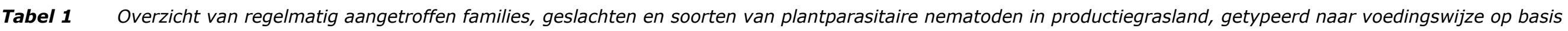
van Yeates et al. (1993).

\begin{tabular}{|c|c|c|c|c|}
\hline Voedingswijze & Familie & Geslacht & Vaak aangetroffen soort & Referenties \\
\hline $\begin{array}{l}\text { Sedentaire } \\
\text { endoparasiet }\end{array}$ & Heteroderidae & Heterodera & Heterodera avenae & Oostenbrink 1957a; Sturhan 1982; Cook et al. 1992; Cook en Yeates 1993; Fleming et al. 2016 \\
\hline $\begin{array}{l}\text { Sedentaire } \\
\text { endoparasiet }\end{array}$ & Heteroderidae & Heterodera & Heterodera mani & Maas en Brinkman 1977; Sturhan 1982; Cook en Yeates 1993 \\
\hline $\begin{array}{l}\text { Sedentaire } \\
\text { endoparasiet }\end{array}$ & Heteroderidae & Heterodera & Heterodera bifenestra & Sturhan 1982; Cook et al. 1992; Cook en Yeates 1993 \\
\hline $\begin{array}{l}\text { Sedentaire } \\
\text { endoparasiet }\end{array}$ & Heteroderidae & Punctodera & Punctodera punctata & Oostenbrink 1957a; Sturhan 1982; Cook et al. 1992; Fleming et al. 2016 \\
\hline $\begin{array}{l}\text { Sedentaire } \\
\text { endoparasiet }\end{array}$ & Meloidogynidae & Meloidogyne & Meloidogyne naasi & Cook et al. 1992; Cook en Yeates 1993; Bell et al. 2006; Fleming et al. 2016 \\
\hline $\begin{array}{l}\text { Vrijlevende } \\
\text { endoparasiet }\end{array}$ & Pratylenchidae & Pratylenchus & Geen specifieke soort & $\begin{array}{l}\text { Oostenbrink 1954, 1957a; Eissa 1971; Ennik en Baan Hofman 1977; Cook et al. 1992; Cook en Yeates } \\
\text { 1993; Verschoor et al. 2001; Mercer et al. 2008; Fleming et al. } 2016\end{array}$ \\
\hline Semi-endoparasiet & Hoplolaimidae & Helicotylenchus & $\begin{array}{l}\text { Helicotylenchus } \\
\text { pseudorobustus }\end{array}$ & $\begin{array}{l}\text { Ennik en Baan Hofman 1977; Cook et al. 1992; Cook en Yeates 1993; Verschoor et al. 2001; Fleming et al. } \\
2016\end{array}$ \\
\hline Semi-endoparasiet & Hoplolaimidae & Rotylenchus & $\begin{array}{l}\text { Rotylenchus robustus (nu } R \text {. } \\
\text { uniformis) }\end{array}$ & Oostenbrink 1957a; Eissa 1971; Simons 1973; Boag en Neilson 1996 \\
\hline $\begin{array}{l}\text { Vrijlevende } \\
\text { ectoparasiet }\end{array}$ & Dolichodoridae & Tylenchorhynchus & Tylenchorhynchus dubius & $\begin{array}{l}\text { Oostenbrink 1954, 1957a,b; Eissa 1971; Ennik en Baan Hofman 1977; Den Toom 1988a; Cook et al. 1992; } \\
\text { Cook en Yeates } 1993\end{array}$ \\
\hline $\begin{array}{l}\text { Vrijlevende } \\
\text { ectoparasiet }\end{array}$ & Tylenchulidae & Paratylenchus & Geen specifieke soort & $\begin{array}{l}\text { Oostenbrink 1954, 1957a,b; Eissa 1971; Ennik en Baan Hofman 1977; Cook et al. 1992; Cook en Yeates } \\
\text { 1993; Fleming et al. } 2016\end{array}$ \\
\hline $\begin{array}{l}\text { Vrijlevende } \\
\text { ectoparasiet }\end{array}$ & Longidoridae & Longidorus & Longidorus elongatus & Ennik en Baan Hofman 1977; Seinhorst en Kozlowska 1979; Cook en Yeates 1993; Fleming et al. 2016 \\
\hline $\begin{array}{l}\text { Vrijlevende } \\
\text { ectoparasiet }\end{array}$ & Longidoridae & Xiphinema & Xiphinema diversicaudatum & Roberts en Cotten 1979; Cook en Yeates 1993 \\
\hline $\begin{array}{l}\text { Vrijlevende } \\
\text { ectoparasiet }\end{array}$ & Anguinidae & Subanguina & Subanguina radicicola & Oostenbrink 1953; Cook en Yeates 1993 \\
\hline $\begin{array}{l}\text { Vrijlevende } \\
\text { ectoparasiet }\end{array}$ & Trichodoridae & Trichodorus & Geen specifieke soort & - \\
\hline $\begin{array}{l}\text { Vrijlevende } \\
\text { ectoparasiet }\end{array}$ & Trichodoridae & Paratrichodorus & Geen specifieke soort & - \\
\hline $\begin{array}{l}\text { Vrijlevende } \\
\text { ectoparasiet }\end{array}$ & Criconematidae & - & Geen specifieke soort & - \\
\hline
\end{tabular}

12 | Wageningen Livestock Research Rapport 1142 


\subsubsection{Invloed van waardplanten}

Welke soorten PPN in welke aantallen worden aangetroffen is afhankelijk van een groot aantal factoren, waaronder bodemtype, bodemsamenstelling, bemesting, graslandmanagement etc. Een belangrijke bepalende factor is de botanische samenstelling van de graszode, omdat de aanwezigheid van bepaalde soorten nematoden in sterke mate wordt bepaald door de aanwezigheid van hun (specifieke) waardplanten. Dit zijn niet alleen grassen maar ook kruiden. De botanische samenstelling van de zode is daarmee een indicator voor de nematodensoorten die in de bodem aanwezig zijn. Andersom kan de diversiteit in aangetroffen nematoden ook gebruikt worden als indicator voor aanwezige plantensoorten. Wanneer bijvoorbeeld Heterodera trifolii en Meloidogyne hapla in de bodem worden aangetroffen, is er vrijwel zeker witte klaver (Trifolium repens) in de graszode aanwezig. Beide soorten nematoden zijn namelijk primaire pathogenen van witte klaver (Yeates 1977). Als Pratylenchus penetrans wordt gevonden, is het waarschijnlijk dat er andere gras- en plantensoorten dan Engels raaigras aanwezig zijn, omdat Engels raaigras een (veel) minder goede waardplant is voor P. penetrans dan bijvoorbeeld witte klaver, timotheegras (Phleum pratense) of kweekgras (Elytrigia repens) (Thies et al. 1995). Raaigrassen zijn in het algemeen matige waardplanten voor het geslacht Pratylenchus (Kimpinski et al. 1984; Thies et al. 1995), met een mogelijke uitzondering voor $P$. neglectus (Wetzel 1969). Kropaar is een goede waardplant voor Meloidogyne chitwoodi (Griffin et al. 1984), een quarantaine organisme in Nederland. De aanwezigheid van kropaar in een graszode kan daarmee de oorzaak zijn van de aanwezigheid van M. chitwoodi.

Oud grasland heeft meestal een meer diverse botanische samenstelling dan jong, heringezaaid grasland, en kan daardoor een meer diverse nematodenfauna bevatten. In het nematodenonderzoek worden met enige regelmaat (landelijke) karteringen van de diversiteit van de nematodenfauna uitgevoerd, zoals bijvoorbeeld door Cook et al. (1992) in de UK en door Fleming et al. (2016) in Noord-Ierland. Gezien het effect van de plantensoortsamenstelling in de graszode op deze diversiteit is het wenselijk om een kartering van nematoden te combineren met kartering van plantensoorten.

\subsubsection{Schadelijke soorten}

\section{Sedentaire endoparasieten}

Binnen de vaak aangetroffen groep cystevormende sedentaire endoparasieten worden de soorten Heterodera avenae, $H$. mani en $H$. bifenestra in verband gebracht met schade aan nieuw ingezaaid grasland (Cook en Yeates 1993). Cook et al. (1992) stellen dat er geen bewijs is dat $H$. avenae en $H$. bifenestra schade aan bestaand grasland veroorzaken. Aantasting door $H$. mani kan mogelijk wel economische schade geven, zowel bij de inzaai van grasland als in bestaand grasland. In een potproef van Maas en Brinkman (1977) gaf inoculatie van de grond met $H$. mani een opbrengstreductie van Engels raaigras tot 54\%, opgeteld over vier sneden. Voor Punctodera punctata werd geen bewijs van schadelijkheid in grasland gevonden. Omdat zowel $H$. mani als $P$. punctata beide sedentaire endoparasieten zijn (Yeates et al. 1993), bekend om hun hoge energiebehoefte en duidelijke schade aan wortelweefsel, zou verwacht worden dat ook $P$. punctata economische schade kan veroorzaken. Een verschil in het aantal jaarlijkse voortplantingscycli, twee voor H. mani (Maas en Brinkman 1977) en waarschijnlijk één voor $P$. punctata (Radice 1985), kan het verschil in schadeniveau verklaren.

Bij de niet-cystevormende endoparasieten wordt Meloidogyne naasi (wortelknobbelnematode) vaak in verband gebracht met het slecht aanslaan en een matige persistentie van raaigras en wordt schade vaak geassocieerd met natte, verdichte en verzuurde grond (Cook en Yeates 1993).

Vrijlevende en semi-endoparasieten

Bij de vrijlevende endoparasieten wordt het wortellesieaaltje (Pratylenchus spp.) beschouwd als een plaag van raaigras in Nieuw-Zeeland, Frankrijk en de VS (Oregon) (Cook en Yeates 1993). Er zijn echter maar een paar schadebeoordelingen gemaakt en er worden geen specifieke bestrijdingsmaatregelen aanbevolen (Cook en Yeates 1993). Oostenbrink (1954) suggereerde dat $P$. pratensis schade aan nieuw ingezaaid en bestaand grasland veroorzaakt. Echter, de schade aan het nieuw ingezaaide gras was in het onderzoek van Oostenbrink (1954) waarschijnlijk het resultaat van de opgebouwde hoge dichtheden onder het vorige gewas snijmaïs (Zea mays). De schade aan het bestaande grasland was waarschijnlijk het gevolg van de aanwezigheid van andere plantensoorten dan 
Engels raaigras in de graszode, aangezien Engels raaigras voor de meeste Pratylenchus soorten een matige tot slechte waardplant is (Kimpinski et al. 1984; Thies et al. 1995). Semi-endoparasieten van het geslacht Helicotylenchus werden door Perry et al. (1959) geassocieerd met groeidepressie van veldbeemgras (Poa pratensis L.) in de zomer ('summer dormancy'). De toediening van nematiciden leidde tot een verbeterde beworteling en hogere opbrengst. Informatie over schade door Rotylenchus uniformis (voor 1996 benoemd als $R$. robustus) werd niet gevonden.

\section{Vrijlevende ectoparasieten}

Bij de vrijlevende ectoparasieten wordt het geslacht Tylenchorhynchus soms geassocieerd met schade. Volgens Cook en Yeates (1993) is een toename in de grasopbrengst na toediening van nematiciden vaak gerelateerd aan een afname van de aantallen van Tylenchorhynchus spp., waaronder T. dubius, T. maximus en soms T. claytoni. Hieruit kan schade door deze soorten afgeleid worden. Den Toom (1990) concludeerde dat aantasting door T. dubius een negatief effect heeft op de wateropname van Engels raaigras. Bij een beperkte beschikbaarheid van water, zoals bij droogte onder veldomstandigheden, kan de grasopbrengst negatief beïnvloed worden. Duidelijke symptomen van aantasting door $T$. dubius werden in deze potproeven, met ruime watervoorziening, echter niet waargenomen (Den Toom 1988a). Mogelijke schade door een gereduceerde wateropname onder veldomstandigheden kan ook afgeleid worden uit potproeven met de vrijlevende ectoparasieten Longidorus elongatus (Seinhorst en Kozlowska 1979) en Xiphinema diversicaudatum (Roberts en Cotten 1979). Schade door de ectoparasiet Subanguina radicicola wordt, evenals bij Meloidogyne naasi, in verband gebracht met vernatting en verdichting van de grond, maar wordt als economisch onbelangrijk beschouwd (Cook en Yeates 1993). Binnen het geslacht Trichodorus is de soort T. teres een schadelijke parasiet van (akkerbouw)gewassen, maar voornamelijk op gronden met een organische stofgehalte lager dan $2 \%$ en een lutumgehalte van 3-8\% (De La Lande Cremer 1965). Woldring (1972) meldde positieve effecten van (algemene) bestrijdingsmaatregelen tegen PPN op grasland met verhoogde dichtheden van $T$. teres, maar deze effecten kunnen ook anders verklaard worden en lijken onvoldoende bewijs voor schadelijkheid van $T$. teres in grasland. Verder is het gehalte organische stof in blijvend grasland meestal (aanzienlijk) hoger dan $2 \%$, wat de kans op schade door $T$. teres minder waarschijnlijk maakt. Informatie over schade aan grasland door geslacht Paratylenchus, Paratrichodorus, of de familie Criconematidae, werd niet gevonden.

\subsection{Schademechanismen}

\subsubsection{Zichtbare schadesymptomen}

Bij de (her)inzaai van grasland kan het afsterven van kiemplanten een symptoom zijn van aantasting door nematoden. Bij bestaand grasland is (ernstige) schade door nematoden bovengronds zichtbaar aan een verstoorde plantengroei, achterblijvende groei, en vergeling of sterfte. De symptomen lijken op de symptomen van een vocht- of nutriëntentekort en komen vaak in plekken voor. Op de wortels zijn bruine plekjes (lesies) zichtbaar, daar waar de nematoden de wortelcellen hebben aangeprikt of de wortels zijn binnengedrongen. Het wortelstelsel kan misvormd zijn, o.a. door de vorming van wortelknobbels en 'wortelbaarden'. De worteltoppen zijn of lijken vaak dood (bruin verkleurd) en de fijnere zijwortels en wortelharen kunnen grotendeels afgestorven zijn. Plantparasitaire nematoden kunnen zowel directe als indirecte schade aan gras veroorzaken. Directe schade ontstaat door de onttrekking van assimilaten uit wortelcellen en het lekken van assimilaten uit de beschadigde cellen. Indirecte schade wordt veroorzaakt door de gevolgen van wortelbeschadiging, zoals een verminderde wateropname, een verminderde nutriëntenopname en een grotere gevoeligheid van het wortelweefsel voor aantasting door andere pathogenen. De diverse schadevormen worden hieronder verder uitgewerkt.

\subsubsection{Directe schade}

Aantasting door nematoden veroorzaakt directe schade door de onttrekking van cytoplasma uit wortelcellen (Verschoor 2002) en daarmee van o.a. koolhydraten en eiwitten. Hierdoor neemt de bruto oogstbare opbrengst af en ontstaat 'opbrengstderving'. Verschoor (2002) berekende een directe jaarlijkse opbrengstreductie van $4,1 \%$ van de totale biomassa en $7,6 \%$ van de wortelbiomassa, voor 
het meest recent bemeste perceel uit zijn onderzoek aan (onbemest) natuurgrasland. Uit aangeprikte en daardoor beschadigde cellen kan cytoplasma lekken, wat bijdraagt aan de opbrengstderving (Yeates et al. 1999). Scott (1979) veronderstelde dat tot $50 \%$ van de totale consumptie door nematoden op deze manier verspild wordt. In dat geval verdubbelt de jaarlijkse directe opbrengstderving, zoals berekend door Verschoor (2002), tot $8 \%$ van de totale biomassa. Het gebruik van koolhydraten om beschadigde cellen te herstellen of te vervangen (Den Toom 1990) kan het niveau van directe schade verder verhogen, maar informatie over deze bijdrage werd niet gevonden. Ferris (1982) demonstreerde met een hypothetische berekening dat er tussen soorten nematoden grote verschillen zijn in directe consumptie. De directe consumptie hangt daarbij niet alleen af van het aantal nematoden, hun gewicht en grootte, maar ook van hun levenswijze, voedingsgewoonten, voortplantingssnelheid en voortplantingsstrategie. Ferris (1982) berekende voor een sedentaire endoparasiet van het geslacht Meloidogyne een jaarlijkse calorische consumptie van 52977 calorieën, maar voor een vrijlevende ectoparasiet van het geslacht Paratylenchus een consumptie van slechts 17 calorieën.

\subsubsection{Indirecte schade}

Een vervormd wortelstelsel vermindert de toegang tot vocht en nutriënten

Beschadiging van wortelcellen, en vervolgens een vervorming van het wortelstelsel, leidt tot indirecte schade of gevolgschade. Vervormingen en het afsterven van wortels geven een oppervlakkiger en minder dicht wortelstelsel, waardoor de toegang van de plant tot de voorraad water en nutriënten in de bodem afneemt. Oostenbrink (1954) beschrijft de schade aan het wortelstelsel van Engels raaigras als gevolg van aantasting door Pratylenchus. Eerst wordt de wortelepidermis gepenetreerd, wat leidt tot het ontstaan van kleine lesies. Daarna ontstaat meestal een dicht en chaotisch wortelstelsel ('wortelbaard'), donker van kleur door de vele lesies en dode wortelpunten. Door het samenvloeien van lesies kunnen zijwortels 'geringd' worden en afsterven. Uiteindelijk resteren kale, bruine en rottende wortelstompen (Oostenbrink 1954). Griffin et al. (1984) geeft een beschrijving van schade aan het wortelstelsel van kropaar als gevolg van aantasting door Meloidogyne chitwoodi. De aantasting leidde tot asymmetrie, fragmentatie, en zelfs vernietiging van de stele (centrale cilinder) door de vorming van reuzencellen (syncytia). Deze reuzencellen wordt gevormd door de versmelting van gewone cellen onder invloed van door nematoden uitgescheiden stoffen en vormen de voedingssites voor jonge nematoden (Jones en Goto 2011). Abnormale groei/ontwikkeling van de zijwortels kwam veel voor. Soms blokkeerden opgezwollen vrouwelijke nematoden de hele dwarsdoorsnede van de hoofdwortel, waardoor ook het normale vasculaire transport van water, nutriënten en assimilaten gehinderd werd.

\section{Lagere vochtopname door beschadigde wortelcellen}

De opname van water en nutriënten kan ook afnemen door een verminderde permeabiliteit van beschadigde wortelcellen. Den Toom (1990) concludeerde dat negatieve effecten van de vrijlevende ectoparasiet Tylenchorhynchus dubius op de groei van Engels raaigras niet het gevolg waren van de directe onttrekking van assimilaten uit het wortelsap (0,1-1\% van de totale productie), of van negatieve effecten op de ontwikkeling van het wortelstelsel, maar eerder van negatieve effecten op de permeabiliteit van wortelcellen. Doordat aangeprikte cellen (tijdelijk) hun celspanning verloren of afstierven, nam de permeabiliteit van de wortelcortex voor water af. Seinhorst en Kozlowska 1979) constateerden dat een relatief zware aantasting van Engels raaigras door Longidorus elongatus in potproeven wel een negatief effect had op de graswortelgroei en wateropname, maar niet op de bovengrondse opbrengst en nutriëntenopname (overigens wel op de ondergrondse opbrengst). Het ontbreken van negatieve effecten in potproeven werd door hen verklaard vanuit een overcapaciteit van een normaal ontwikkeld wortelstelsel voor het opnemen van water en nutriënten. Elkins et al. (1979) rapporteerden dat aantasting van de wortels van rietzwenkgras door de semi-endoparasiet Hoplolaimus galeatus de wateropname verminderde, met $16-17 \%$ bij een grasgenotype met veel en dunne wortels en met $45-50 \%$ bij een genotype met minder en dikkere wortels. Yeates et al. (1975) constateerden dat wanneer grasland met witte klaver, en aanwezigheid van Heterodera trifolii, werd ontsmet en heringezaaid met witte klaver, de groei in de droge zomerperiode langer doorging.

Ontsmetting gaf waarschijnlijk minder schade aan het wortelstelsel, waardoor de klaverplanten in de droge periode de afnemende hoeveelheid bodemvocht beter konden benutten.

Lagere nutriëntenopname door beschadigde wortelcellen 
Een verminderde permeabiliteit van wortelcellen kan ook leiden tot een verminderde nutriëntenopname, maar hiervoor werd voor Engels raaigras geen bewijs gevonden. Den Toom (1990) constateerde dat een opbrengstreductie van Engels raaigras na aantasting door Tylenchorhynchus dubius niet verklaard kon worden door symptomen van een nutriëntentekort. Seinhorst en Kozlowska 1979) constateerden dat een relatief zware aantasting door Longidorus elongatus wel een negatief effect had op de wortelgroei en wateropname van Engels raaigras, maar niet op de nutriëntenopname. Elkins et al. (1979) constateerden dat na aantasting van rietzwenkgras door PPN de totale K- en Caopname vrijwel proportioneel afnam met de opbrengst, terwijl de Mg-opname wat sterker afnam. Bij witte klaver moesten Yeates (1974) $300 \mathrm{~kg} \mathrm{P} \mathrm{ha}^{-1}$ met superfosfaat extra toedienen wanneer de klaver werd gezaaid in grond met Heterodera trifolii, om dezelfde opbrengst te realiseren als bij zaaien in grond zonder $H$. trifolii. Dit effect werd verklaard door een verminderde P-opname van beschadigde wortels in de grond met $H$. trifolii. Widdowson et al. (1972) moesten in een potexperiment bij de aanwezigheid van PPN meer dan vijf keer de hoeveelheid P toedienen om eenzelfde klaveropbrengst te realiseren als na ontsmetting. Een kanttekening bij deze resultaten is dat witte klaver waarschijnlijk gevoeliger is voor een nutriëntentekort door wortelschade dan Engels raaigras, omdat witte klaver minder wortels heeft.

Verhoogde gevoeligheid van het wortelweefsel voor aantasting door andere pathogenen Aantasting door PPN gaat vaak samen met aantasting door andere pathogenen in een zogenoemd 'ziektecomplex'. Back et al. (2002) reviewden mogelijke interacties tussen pathogene bodemschimmels en PPN. Bij deze interacties zijn meestal endoparasitaire nematoden (vaak Meloidogyne spp.) betrokken. Dergelijke interacties kunnen synergistisch zijn (toenemende schade; 1 $+1>2$ ), antagonistisch (afnemende schade, $1+1<2$ ) of neutraal (gelijke schade, $1+1=2$ ). Enkele mogelijke mechanismen zoals beschreven door Back et al. (2002) worden hier kort weergegeven. Door PPN veroorzaakte schade aan wortelweefsel, zoals lesies, gespleten wortelgallen, indringingskanalen en voedingssites, kunnen door bodemschimmels gebruikt worden om de plant binnen te dringen. Dit mechanisme lijkt echter alleen te werken als schimmels en PPN tegelijk actief zijn. Wanneer schade door nematoden een paar weken eerder optreedt dan aantasting door schimmels, kan de ontwikkeling van necrotisch weefsel het risico van een schimmelinfectie verkleinen. Hierdoor kan de interactie veranderen van potentieel synergistisch naar antagonistisch. Het lekken van cytoplasma uit beschadigde wortelcellen kan schimmels aantrekken en daardoor het risico van infectie vergroten. Nutriëntenrijke reuzencellen zijn ook een aantrekkelijk infectiepunt voor schimmels en kunnen als voedselbasis gebruikt worden om van daaruit andere plantenweefsels te infecteren. Een synergistische interactie tussen een schimmel en nematode kan leiden tot het afbreken van resistentie tegen aantasting door een schimmel of nematode. Nematoden kunnen met hun stekel door een barrière, zoals de wortelepidermis, dringen, die eerst ondoorlaatbaar was voor de schimmel, en een schimmel kan enzymen produceren die de wortelepidermis verzwakken, waardoor nematoden deze eerder kunnen binnendringen.

Zowel biotische als abiotische factoren kunnen de ontwikkeling van en schade door een ziektecomplex beïnvloeden. Sommige ectoparasitaire nematodengeslachten, zoals Trichodorus en Tylenchorhynchus, worden vrijwel niet genoemd als onderdeel van een ziektecomplex, waarschijnlijk omdat ze door hun oppervlakkige voedingswijze alleen geringe schade aan het wortelweefsel veroorzaken (Back et al. 2002). Nematoden met een relatief lange stekel of speer, welke diep doordringen in het wortelweefsel en zich voeden in de nabijheid van de centrale cilinder, worden beschouwd als belangrijke vectoren van plantenvirussen (Back et al. 2002). Voorbeelden hiervan zijn de geslachten Xiphinema en Longidorus (Back et al. 2002) en de soort Hemicycliophora conida (Boag 1980). Virussen kunnen echter ook overgebracht worden door ectoparasieten met een korte stekel (Leendert Molendijk, pers. med.). Een virusinfectie veroorzaakt door een nematode leidt tot indirecte schade en een infectie kan mogelijk verder toenemen door synergistische interactie. Nematoden kunnen mogelijk ook vector zijn voor bacterie- en schimmelsporen, maar daarvoor werd weinig tot geen bewijs gevonden.

\subsubsection{Invloed van groeistadium en groeiomstandigheden}

Het ontstaan van schade na aantasting door nematoden hangt van meerdere factoren af. Schade ontstaat eerder tijdens kwetsbare periodes gedurende de groei en ontwikkeling van het gras, zoals tijdens de kiemplantfase en direct na oogst (Cook et al. 1992). Kiemplanten zijn kwetsbaarder dan 
volwassen planten, vooral bij herinzaai, omdat de kleine kiemplanten dan de enige voedselbron zijn voor de volwassen populatie nematoden die na vernietiging van de graszode achterblijft (Van Bezooijen en Murray 1989). Bestrijding van nematoden tijdens herinzaai beschermt de kiemplanten tijdens deze kritische fase van wortelontwikkeling, waardoor de opbrengst kan toenemen (Oostenbrink 1954; Van Bezooijen en Murray 1989; Lewis et al. 1991). Oostenbrink (1954) rapporteerde een betere ontwikkeling en groei van een mengsel van Engels raaigras en witte klaver door het toepassen van ontsmetting bij de herinzaai van oud grasland. De relatieve opbrengsttoename in de eerste snede van gemiddeld $77 \%$ kon niet worden behaald met een zware N-bemesting. Van Bezooijen en Murray (1989) rapporteerden dat grondontsmetting bij herinzaai in de herfst resulteerde in een opbrengsttoename van gemiddeld $11 \%$ in de eerste snede van het volgende groeiseizoen. Ook nam de onkruiddruk sterk af, waarschijnlijk omdat de kiemplanten na ontsmetting zich beter ontwikkelden en beter konden concurreren met niet-gezaaide soorten. Na de eerste snede waren de effecten op de opbrengst klein (Van Bezooijen 1979; Van Bezooijen en Murray 1989). Den Toom (1988a) concludeerde dat schade door PPN in potproeven vooral het gevolg was van beschadiging van de seminale wortels tijdens de kiemplantfase, en dat de schade daarna, tijdens vorming van adventieve wortels, niet meer toenam. De afnemende gevoeligheid voor schade tijdens de wortelontwikkeling kan volgens den Toom (1988a) ook verklaard worden door een toename van de fractie oude wortels, waar de nematoden niet op kunnen voeden.

Schade door PPN kan verschillend zijn bij verschillende groeiomstandigheden en in verschillende groeiseizoenen (Oostenbrink 1954). Gesteld kan worden dat een gewas schadegevoeliger wordt bij ongunstigere groeiomstandigheden. Groeiomstandigheden die het gewas, via het wortelstelsel, stress geven en kwetsbaar maken, zoals een vochttekort, nutriëntentekort, bodemverdichting, -vernatting en -verzuring, kunnen leiden tot grotere schade. Dit is vooral goed zichtbaar wanneer gras voor recreatieve doeleinden wordt gebruikt, zoals op golfbanen en sportvelden. Cook en Yeates (1993) rapporteerden dat schade aan grasland door Meloidogyne naasi en Subanguina radicicola vaak wordt geassocieerd met verdichte, natte en zure grond. Deze associatie betekent niet zozeer dat de nematoden het onder deze omstandigheden goed doen, maar eerder dat deze wortelstressfactoren de grasplanten verzwakken, waardoor ze gevoeliger zijn voor schade (Cook et al. 1992; Cook en Yeates 1993). Uit potproeven met Engels raaigras kan afgeleid worden dat bij een optimale water- en nutriëntenvoorziening de door PPN veroorzaakte wortelschade een veel kleiner effect heeft op de wateropname, nutriëntenopname en bovengrondse opbrengst, dan in een situatie met tekorten (Den Toom 1988a; Roberts en Cotten 1979; Seinhorst en Kozlowska 1979). Aantallen PPN die in potproeven geen duidelijke schade veroorzaken kunnen daardoor onder veldomstandigheden wel tot duidelijke schade leiden.

De omgevingstemperatuur kan een groot effect hebben op de relatieve schade (bijvoorbeeld in de vorm van relatieve opbrengstderving) wanneer nematoden actief zijn bij een temperatuur waarbij de waardplant niet groeit. Boag (1980) liet zien dat Xiphinema diversicaudatum en Hemicycliophora conida zich al vanaf een temperatuur van $5^{\circ} \mathrm{C}$ voeden aan de wortels van Engels raaigras, terwijl Rotylenchus robustus (sinds 1996 benoemd als $R$. uniformis) al bij een temperatuur van $0,5^{\circ} \mathrm{C}$ actief is. Omdat Engels raaigras pas groeit bij een temperatuur vanaf $\sim 8^{\circ} \mathrm{C}$ kan de relatieve schade door deze nematodensoorten groter zijn bij een lagere temperatuur.

\subsubsection{Schadedrempels}

Nematoden kunnen een gewas beschadigen zonder merkbare gevolgen, zoals in de vorm van een opbrengstderving. De dichtheid nematoden waarboven dit wel het geval is, wordt de schadedrempel genoemd. In dit rapport wordt met schade meestal opbrengstderving bedoeld en is de definitie van de schadedrempel de dichtheid nematoden waarboven de oogstbare opbrengst duidelijk begint af te nemen. De afhankelijkheid van het schadeniveau van de groeiomstandigheden (Paragraaf 3.3.4) maakt het lastig om betrouwbare schadedrempels vast te stellen. Daarnaast zijn er ook andere complicerende factoren. $Z o$ is het gemeten aantal nematoden afhankelijk van de gebruikte monstername- en extractiemethode. Omdat er internationaal verschillende methoden gebruikt worden, met verschillende extractieëfficienties (Verschoor en De Goede 2000), kunnen verschillende studies verschillende schadedrempels geven. Bij het vaststellen van schadedrempels op basis van veldexperimenten speelt ook de bemonsteringsdiepte een belangrijke rol, omdat beneden de gekozen 
10 of $20 \mathrm{~cm}$ bemonsteringsdiepte nog behoorlijke aantallen nematoden aanwezig kunnen zijn (Yeates 1977; Verschoor et al. 2001). Bij potproeven is het daarnaast altijd de vraag hoe de resultaten zich verhouden tot veldomstandigheden. In potproeven is de water- en nutriëntenvoorziening meestal optimaal, waardoor er bij dezelfde nematodendichtheid minder snel schade ontstaat als onder veldomstandigheden (Paragraaf 3.3.4). Wanneer in potonderzoek het gras gezaaid wordt in grond met (verhoogde) aanwezigheid van PPN, kan de opbrengstreductie door schade aan de kiemplantjes disproportioneel groot zijn (Paragraaf 3.3.4), zeker aan het begin van de proef. Resultaten uit potproeven zijn daarom slecht vergelijkbaar met resultaten uit veldproeven. Uit het oogpunt van volledigheid, en ook om de voorgaande kanttekeningen te illustreren, wordt hieronder toch een overzicht van gevonden schadedrempels gegeven.

\section{Sedentaire endoparasieten}

$\mathrm{Bij}$ de sedentaire endoparasieten worden sommige soorten cystenematoden geassocieerd met belangrijke opbrengstverliezen na de inzaai van Engels raaigras in grond met hoge dichtheden van deze soorten. In onderzoek van Cook en Yeates (1993) ging het daarbij om dichtheden van 25.000 eieren $100 \mathrm{ml}^{-1}$ grond voor Heterodera avenae en 10.000 eieren $100 \mathrm{ml}^{-1}$ grond voor $H$. mani of $H$. bifenestra. Voor de niet-cystevormende endoparasiet Meloidogyne naasi rapporteerden Cook en Yeates (1993) dat grondontsmetting voor de inzaai van Engels raaigras de jaaropbrengst met $22 \%$ verhoogde, bij een dichtheid van 3800 juvenielen $100 \mathrm{ml}^{-1}$ grond. Cook en Yeates (1993) rapporteerden voor een potproef bij een dichtheid van 22.000 jonge nematoden per $100 \mathrm{ml}$ grond een opbrengstreductie van $51 \%$ in drie maanden, en voor een veldproef geen effect bij een dichtheid van 6.000 jonge nematoden per $100 \mathrm{ml}$ grond.

\section{Vrijlevende endoparasieten}

Bij de vrijlevende endoparasiet Pratylenchus pratensis beschouwde Oostenbrink (1954) dichtheden van 100 tot 200 nematoden per $100 \mathrm{ml}$ grond als relatief hoog en een dichtheid van 865 nematoden per $100 \mathrm{ml}$ grond als een zware aantasting. Kiemplanten van Engels raaigras ondervonden bij deze laatste dichtheid in een potproef een sterke groeireductie, die alleen kon worden opgeheven door ontsmetting. In een andere potproef, met gebruik van dezelfde grond, gaf ontsmetting gevolgd door inzaai van Engels raaigras een verdubbeling van de wortelmassa en verdrievoudiging van de bovengrondse opbrengst na 70 dagen, vergeleken met de controle (Oostenbrink 1954). Wetzel (1969) constateerde geen zichtbare schadesymptomen voor Pratylenchus neglectus bij een dichtheid van 1106 nematoden g wortelmassa ${ }^{-1}$.

\section{Vrijlevende ectoparasieten}

Bij de vrijlevende ectoparasieten van het geslacht Tylenchorhynchus werd een begindichtheid van 540 nematoden $100 \mathrm{ml}^{-1}$ grond (in bodemlaag 0-20 cm) geassocieerd met een opbrengstreductie van $18 \%$ over een periode van meer dan twee jaar na de herinzaai van grasland (Spaull et al. 1985). Voor Tylenchorhynchus claytoni gaf een begindichtheid van 67 nematoden $100 \mathrm{ml}^{-1}$ grond een opbrengstreductie van $30 \%$ in latere oogsten, in een negen maanden durende potproef (McGlohon et al. 1961). Voor Tylenchorhynchus dubius rapporteerde Den Toom (1990) een opbrengstreductie van Engels raaigras vanaf dichtheden van 1300 nematoden $100 \mathrm{~g}^{-1} \mathrm{grond}$, in potproeven en bij een temperatuur van $18^{\circ} \mathrm{C}$. In veldonderzoek van Ennik en Baan Hofman (1977) nam de dichtheid van Paratylenchus spp. toe tot 7.000 nematoden $100 \mathrm{ml}^{-1}$ grond (het totale aantal Tylenchidae tot 10.000) zonder een effect op de opbrengst van de vijfde snede gras. Voor Longidorus elongatus vonden Seinhorst en Kozlowska (1979) bij begindichtheden van 3700 nematoden $100 \mathrm{~g}^{-1}$ grond in een potproef geen effect op de bovengrondse opbrengst, alhoewel bij meer dan 40 nematoden $100 \mathrm{~g}^{-1}$ grond de wortelgroei werd verstoord en de wateropname en wortelmassa sterk afnamen. In een potproef van Roberts en Cotten (1979) reduceerden begindichtheden van Xiphinema diversicaudatum van 100 nematoden $100 \mathrm{ml}^{-1}$ grond (82 nematoden aan het einde) de lengte van het wortelstelsel van Engels raaigras met $28 \%$. De wortelbiomassa en bovengrondse groei werden echter niet beïnvloed. 


\subsection{Geschat niveau van opbrengstderving}

\subsubsection{Schattingsmethoden}

Schade door nematoden aan grasland kan duidelijk tot uiting komen in een derving van de grasopbrengst. Om het niveau van deze derving te schatten kunnen meerdere methoden gebruikt worden. Een eerste methode is het berekenen van de voedselbehoefte (energetische consumptie) van de aanwezige populatie nematoden in grasland. Een tweede methode is om in een pot- of veldproef de gebruikte grond wel of niet te inoculeren met PPN, gras te zaaien en vervolgens het effect van de beginpopulatie op de ontwikkeling en opbrengst van het gras vast te stellen. Een derde methode is om, in een pot- of veldproef, grond met daarin PPN wel of niet te ontsmetten, gras te zaaien en het effect van ontsmetting op de grasopbrengst vast te stellen. De voor- en nadelen van iedere methode, en een aantal resultaten, worden hierna besproken.

\subsubsection{Berekening voedselbehoefte}

Een opbrengstderving kan geschat worden door de energetische consumptie van de aanwezige PPN te berekenen. Verschoor (2002) berekende een directe jaarlijkse koolstof(C)consumptie door herbivore nematoden van $4,1 \%$ van de totale biomassa (boven- en ondergronds) en $7,6 \%$ van de wortelbiomassa, voor natuurgrasland dat zes jaar niet meer was bemest. Deze consumptie is lager dan berekend in andere studies, wat Verschoor (2002) wijt aan het door hem gemaakte (gewenste) onderscheid tussen jonge en volwassen nematoden. Verschoor (2002) geeft ook aan dat de schade door volwassen cystenematoden niet is meegenomen en dat daardoor de werkelijke consumptie 30$60 \%$ hoger geweest kan zijn. Daarnaast geeft Verschoor (2002) aan dat door het lekken van wortelsap uit beschadigde cellen de bruto consumptie tot twee keer hoger geweest kan zijn. In dat geval was het verlies van totale biomassa minimaal $8 \%$. Een belangrijk nadeel van de berekeningsmethode is dat gevolgschade en eventuele voordelen van herbivore nematoden niet meegenomen kunnen worden. Het is echter juist de gevolgschade die relatief groot kan zijn, vooral bij aantasting door endoparasieten. Vanwege het grote aantal benodigde aannames voor de berekening van de voedselbehoefte, en het niet mee kunnen nemen van gevolgschade of van voordelen, is deze methode onvoldoende geschikt om een opbrengstderving door PPN betrouwbaar vast te stellen.

\subsubsection{Inoculatieproeven}

Inoculatie wordt meestal toegepast in potproeven en zelden in veldproeven. Oostenbrink (1969) stelde dat inoculatieproeven een onbetrouwbare methode zijn voor het bepalen van schade door nematoden aan gewassen. Door gebruik van te kleine potten wordt er vaak overgedoseerd, het inoculum kan inactief zijn, een aggregatie-effect wordt vaak niet meegenomen en de extractieverliezen kunnen groot zijn. Daarnaast is in potproeven de water- en nutriëntenvoorziening meestal optimaal, waardoor het effect van wortelschade op de opbrengst minder groot is dan onder suboptimale veldomstandigheden (Paragraaf 3.3.4). Verder wordt in potproeven het gras meestal gezaaid, waardoor de schade bij kortdurende proeven disproportioneel groot kan zijn door de schade tijdens de kwetsbare kiemplantfase (Paragraaf 3.3.4). Tenslotte wordt in potproeven vaak gefocust op het effect van een specifieke nematodensoort, terwijl onder veldomstandigheden de nematodenfauna meer divers is.

Twee voorbeelden laten zien hoe groot de effecten van inoculatie in potproeven kunnen zijn. Oostenbrink (1954) rapporteerde dat grondontsmetting door verhitting de wortelmassa van ingezaaid Engels raaigras verdubbelde en de grasopbrengst verdrievoudigde, in een periode van 70 dagen en vergeleken met de onbehandelde controle. Den Toom (1988b) rapporteerde een opbrengstreductie van gemiddeld $29 \%$ in de 30 dagen na inzaai van Engels raaigras in geïnoculeerde grond. De relatief grote opbrengstdervingen in potproeven, wanneer vergeleken met de andere twee methoden, geven aan dat dit type proeven weinig geschikt is om het niveau van opbrengstderving realistisch te bepalen. Potproeven zijn overigens wel goed bruikbaar om te bepalen of een nematodensoort schade aan de wortels veroorzaakt en op welke manier. 


\subsubsection{Ontsmettingsproeven}

Het afleiden van een opbrengstderving uit resultaten van ontsmettingsproeven onder veldomstandigheden verkleint het risico van disproportionele effecten zoals in potproeven. Echter, ontsmetting kan ook positieve effecten op de opbrengst hebben die niet het gevolg zijn van het doden van PPN. Een nematicide kan naast PPN ook niet-schadelijke nematoden en andere bodemorganismen doden. Dit kan leiden tot een tijdelijke piek in $\mathrm{N}$-mineralisatie, gevolgd door een hogere $\mathrm{N}$-opname en opbrengst van het gras (Ennik en Baan Hofman 1977). Een nematicide doodt vaak maar een deel van de PPN (Eissa 1971) en kan ook een groeibevorderend effect op gras hebben (Ennik en Baan Hofman 1977). Ondanks deze nadelen lijkt het afleiden van opbrengstderving uit resultaten van ontsmettingsproeven een geschiktere methode dan inoculatie of ontsmetting in potproeven, of berekening van de voedselbehoefte. Dit geldt vooral wanneer ouder (stabiel) grasland met een goed ontwikkelde en diverse nematodenfauna wordt ontsmet.

Oostenbrink (1957b) constateerde, op basis van ontsmettingsonderzoek, dat PPN verantwoordelijk zijn voor een gemiddelde opbrengstderving van zeker $10 \%$ van de oogstbare opbrengst van landbouwgewassen. Eissa (1971) rapporteerde een toename van de gemiddelde grasopbrengst van $19 \%$ na ontsmetting van 34 willekeurig gekozen gronden (Tabel 7 in Eissa 1971). Bij zeven gronden zonder PPN nam door ontsmetting de opbrengst met gemiddeld $5 \%$ toe. Combinatie van deze resultaten suggereert een gemiddelde opbrengstderving door PPN van 14\%. Echter, omdat het niveau van opbrengstderving afhankelijk is van grondsoort (Eissa 1971; Ennik en Baan Hofman 1977) en deze voor de betrokken gronden niet is aangegeven, kan niet vastgesteld worden of de $14 \%$ representatief is. Bij een aantal gronden met een bekende, verhoogde dichtheid van PPN, nam na ontsmetting de grasopbrengst toe met $37 \%$ tot 53\% (Eissa 1971). Ennik en Baan Hofman (1977) stelden vast dat door ontsmetting met thionazine de jaaropbrengst van grasland met gemiddeld $13 \%$ toenam bij een laag niveau van N-bemesting (300-400 kg N ha-1 jaar $^{-1}$ ) en met $8 \%$ bij een hoog niveau van $\mathrm{N}$-bemesting (400-600 kg N ha-1 $\mathrm{jaar}^{-1}$ ). De absolute opbrengsttoename was voor beide $\mathrm{N}$ niveaus hetzelfde, gemiddeld $1160 \mathrm{~kg} \mathrm{DS} \mathrm{ha}^{-1} \mathrm{jaar}^{-1}$. Deze waarneming demonstreert het positieve effect van een beter groeiend gewas op de relatieve opbrengstderving; deze neemt af bij een hogere opbrengst. Bij het lage niveau van $\mathrm{N}$-bemesting kon de opbrengsttoename als gevolg van ontsmetting ook behaald worden door meer $\mathrm{N}$ te bemesten, maar bij het hoge $\mathrm{N}$-niveau niet. Verder was de opbrengsttoename op jonge zeeklei lager dan op zandgrond. Een directe relatie tussen het aantal aangetroffen PPN en de opbrengstreactie na ontsmetting was soms wel en soms niet aanwezig; een positief effect van thionazine op de grasgroei (groeistimulatie) kon worden uitgesloten. Toepassing van andere, minder specifieke, nematiciden gaf eenzelfde opbrengstrespons terwijl er minder PPN gedood werden. Dit wijst op andere opbrengstverhogende effecten dan alleen door het doden van PPN (zie ook Eissa 1971).

Samenvatting van bovenstaande bevindingen geeft een range in het niveau van jaarlijkse relatieve opbrengstderving van $8 \%$ tot $14 \%$ voor een gemiddeld perceel productiegrasland in Nederland. Deze range bevat ook de effecten van ontsmetting op andere bodemorganismen en op de $\mathrm{N}$-mineralisatie. $\mathrm{Na}$ uitsluiting van de resultaten van het hoge niveau van $\mathrm{N}$-bemesting uit het onderzoek van Ennik en Baan Hofman (1977) (dit niveau is niet meer toegestaan) ligt het niveau van opbrengstderving op 13$14 \%$. Watson et al. (1985) vonden ook een gemiddelde opbrengstderving van $13 \%$ in een brede ontsmettingsproef in Nieuw-Zeeland, maar dan voor grasland met witte klaver. Een gemiddelde opbrengstderving van $13 \%$, of 1,2 ton DS ha-1 jaar $^{-1}$, maakt duidelijk dat PPN een belangrijke rol spelen bij een lagere productiviteit van grasland.

\subsection{Voordelen van plantparasitaire nematoden}

\subsubsection{Introductie}

Plantparasitaire nematoden staan vooral bekend om hun mogelijke negatieve effecten op de opbrengst en kwaliteit van landbouwgewassen. Minder bekend is dat deze groep nematoden ook positieve effecten kan hebben op het functioneren van het agro-ecosysteem. Belangrijke (bekende) 
effecten zijn het stimuleren van de nutriëntenmineralisatie en van biodiversiteit. Deze bijdragen worden hieronder toegelicht.

\subsubsection{Stimuleren van nutriëntenmineralisatie}

Een beperkte aantasting door herbivore nematoden kan een positief effect hebben op de beschikbaarheid van nutriënten en op de snelheid van de nutriëntenkringloop in de bodem. Herbivore nematoden dragen bij aan de beschikbaarheid van $\mathrm{N}$ in de bodem; $90 \%$ van de uit wortelsap opgenomen $\mathrm{N}$ wordt weer uitgescheiden, grotendeels in plantopneembare vorm (Bardgett et al. 1999). Mineralisatie van organisch materiaal afkomstig van de nematoden (uitgescheiden organische $\mathrm{N}$, dode nematoden) draagt ook bij aan een hogere $\mathrm{N}$-beschikbaarheid. Lekkage van sap uit beschadigde wortelcellen kan leiden tot een verhoogde microbiële activiteit (Denton et al. 1999; Yeates et al. 1999) en daardoor tot een hogere mineralisatie van nutriënten, een hogere nutriëntenopname door de plant en uiteindelijk een hogere opbrengst (Bardgett et al. 1999). Herbivore nematoden zijn meestal de dominante functionele groep onder de nematoden in blijvend grasland (Bardgett et al. 1999) en leveren daardoor een belangrijke bijdrage aan de totale N-mineralisatie door nematoden. Door hun voedingswijze kunnen herbivore nematoden een deel van de $\mathrm{N}$-dominantie van hun waardplanten doorbreken en daardoor $\mathrm{N}$ beschikbaar maken die anders voornamelijk via de afbraak van plantenresten beschikbaar zou komen. De positieve effecten van een laag niveau van aantasting door nematoden (ondergrondse begrazing) op de nutriëntenkringloop en op de bovengrondse productie lijken overeen te komen met de positieve effecten van bovengrondse begrazing (beweiding) (Bardgett et al. 1998). Ontbladering, door maaien of grazen, leidt op korte termijn tot meer wortelexudatie, meer microbiële activiteit in de rhizosfeer, een hogere $\mathrm{N}$-mineralisatie en een hogere $\mathrm{N}$-opname door het gewas (Hamilton et al. 2008).

De bijdrage van herbivore nematoden aan de totale $\mathrm{N}$-mineralisatie in de bodem is onduidelijk. Verschoor (2002) berekende een directe bijdrage (via uitwerpselen) van 2-5\%, in natuurgrasland dat al zes jaar niet meer was bemest. Verschoor (2002) gaf echter ook aan dat dit een forse onderschatting kan zijn, omdat in deze berekening niet de lekkage van wortelsap en de $\mathrm{N}$ mineralisatie uit dode nematodenbiomassa was meegenomen. Verder kan in productiegrasland (met een relatief hoge $\mathrm{N}$-bemesting) de bijdrage van herbivore nematoden groter zijn dan in natuurgrasland (zonder N-bemesting). Tu et al. (2003) lieten zien dat de bijdrage van PPN aan de Nmineralisatie behoorlijk groot kan zijn. In hun onderzoek nam bij de teelt van katoen de netto $\mathrm{N}$ mineralisatie toe met $17-117 \%$ na inoculatie van de grond met de sedentaire endoparasiet Rotylenchulus reniformis.

Een belangrijke vraag is in hoeverre de gestimuleerde $\mathrm{N}$-mineralisatie de veroorzaakte schade kan compenseren. Onderzoek aan diverse gewassen laat zien dat de kosten door schade relatief hoog zijn vergeleken met de baten door een verhoogde N-mineralisatie (Tu et al. 2003; Poll et al. 2007; Schoening en Wurst 2016). De mate van compensatie hangt daarbij af van de dichtheid en soortsamenstelling van de nematodenfauna. Bij hoge dichtheden zullen de kosten hoger zijn dan de baten. Kleine, vrijlevende ectoparasieten stimuleren de wortelexudatie meer dan de grotere semiendoparasieten (Yeates et al. 1999), terwijl ze meestal minder schade veroorzaken. Mogelijk dragen daardoor vooral de ectoparasieten bij aan het stimuleren van de $\mathrm{N}$-mineralisatie in productiegrasland.

Productiegrasland wordt relatief zwaar bemest met plantopneembare $\mathrm{N}$ uit kunstmest en drijfmest. Daardoor is de bijdrage van herbivore nematoden/PPN aan de N-mineralisatie in productiegrasland minder belangrijk dan in een natuurlijk ecosysteem, met een kleinere hoeveelheid plantopneembare $\mathrm{N}$ in de kringloop, en weegt deze bijdrage van PPN onvoldoende op tegen de veroorzaakte schade.

\subsubsection{Stimuleren van biodiversiteit}

Herbivore nematoden stimuleren niet alleen de nutriëntenmineralisatie maar ook de biodiversiteit, zowel in als boven de grond. Een belangrijke bijdrage wordt geleverd door hun aantal en diversiteit: nematoden zijn de meest voorkomende en waarschijnlijk ook de meest functionele groep van de bodemfauna, met een grote taxonomische soortenrijkdom (Bardgett et al. 1999). Grasland in een gematigd klimaat bevat meestal tussen de 3 en 4 miljoen nematoden per $\mathrm{m}^{2}$ (Bardgett et al. 1999) en 
er kunnen tot 75 taxa (Yeates et al. 1997) en 150 soorten (Hodda en Wanless 1994a, 1994b) aanwezig zijn, waarvan de meeste tot verschillende voedselgroepen behoren. Van alle nematoden is $28 \%$ tot $53 \%$ herbivoor (Bardgett et al. 1999).

Herbivore nematoden kunnen ook actief de bovengrondse biodiversiteit bevorderen. Verschillende onderzoekers stellen dat aantasting en schade door PPN een rol speelt in de vervanging en opvolging van plantensoorten (Oostenbrink 1954; Van der Putten en Peters 1997; Bardgett et al. 1999; Verschoor et al. 2002; Eisenhauer et al. 2010). Een intensieve aantasting door nematoden van hun waardplant kan leiden tot het verslechteren van de concurrentiepositie en het plaatselijk verdwijnen van deze waardplant. Hierdoor ontstaat ruimte in de graszode voor de uitbreiding van aanwezige soorten of de vestiging van andere soorten. Oostenbrink (1954) noemde in 1954 al de mogelijke rol van herbivore nematoden in het 'verouderen' van grasland, ofwel een daling in productiviteit door verandering van de botanische samenstelling. Van der Putten en Peters (1997) lieten zien dat wanneer van twee plantensoorten er één werd blootgesteld aan zijn gespecialiseerde herbivore nematoden en pathogene schimmels, deze plantensoort werd weggeconcurreerd en vervangen door de andere. Dit effect werd versterkt door een tekort aan nutriënten (zie ook paragraaf 3.3.3). Van der Putten en Peters (1997) concludeerden op basis van deze waarnemingen dat concurrentie door bodempathogenen en plaagdieren, waaronder PPN, een belangrijk mechanisme kan zijn in de vervanging en opvolging van plantensoorten. Bardgett et al. (1999) suggereerden een andere vorm van concurrentie, via de invloed van herbivore nematoden op de N-kringloop in de bodem. Hierdoor kan de concurrentiepositie van de waardplant ook verslechteren. Bij de mengteelt van gras met witte klaver kan een matige aantasting van witte klaver door Heterodera trifolii de overdracht van door klaver gebonden $\mathrm{N}$ naar het gras verhogen en daardoor de positie van het gras in het mengsel versterken, ten koste van de klaver. Eisenhauer et al. (2010) concludeerden dat aantasting door PPN de bovengrondse biomassa van kruiden en grassen wel verlaagde, maar die van leguminosen niet. Parasitaire nematoden verlaagden verder de grasopbrengst wel bij een grote diversiteit aan plantensoorten maar niet bij een kleine diversiteit. Viketoft et al. (2011) vonden, in een acht jaar durend veldonderzoek, geen effect van het constant houden van de botanische samenstelling van grasland op de diversiteit van herbivore nematoden; wel nam het aantal herbivore nematoden in vrijwel alle behandelingen toe en waren er veranderingen in dominantiepatronen. Sohlenius et al. (2011) vonden, in een zeven jaar durend veldonderzoek, dat de diversiteit van herbivore nematoden weinig werd beïnvloed door diversiteit in gras- en andere plantensoorten. Wel waren de dichtheden van parasitaire soorten Tylenchorhynchus dubius, T. maximus en Pratylenchus spp. hoger onder monocultuur (o.a. van timoteegras) vergeleken met mengsels. Wasilewska (1995) vond onder een monocultuur (kropaar) ook hogere dichtheden van het parasitaire geslacht Pratylenchus vergeleken met een mengsel, en daarnaast ook hogere dichtheden van de parasitaire geslachten Heterodera, Meloidogyne en Trichodorus.

In de Nederlandse melkveehouderij ligt bij de grasteelt momenteel de focus op monocultuur van Engels raaigras, vanwege de hoge opbrengst en goede verteerbaarheid. Een toename van het aantal soorten in de graszode geeft meestal een lagere opbrengst en voederwaarde en wordt daarom als ongewenst gezien. Bij een te hoog aandeel ongewenste soorten wordt de graszode omgeploegd en opnieuw ingezaaid. De rol van PPN in het bevorderen van plantensoortenrijkdom is vanuit dit oogpunt geen voordeel, maar een extra nadeel bovenop de schade die PPN al kunnen veroorzaken. Wanneer in productiegrasland actief een hogere soortenrijkdom wordt nagestreefd, zoals bij de teelt van kruidenrijk grasland, dan is dit streven meestal gericht op specifieke (productieve) soorten en niet op algemene soortenrijkdom (inclusief weinig productieve soorten, 'onkruiden').

\subsection{Beheersing van plantparasitaire nematoden}

\subsubsection{Introductie}

Bij grote aantallen kunnen PPN een grote opbrengstderving (37-53\%) veroorzaken en zijn er maatregelen nodig om deze opbrengstderving te beperken. Bij een grote opbrengstderving is eerst van belang om vast te stellen welke soort(en) verantwoordelijk zijn en wat de oorzaak van hun hoge aantal is. Met behulp van deze informatie kunnen vervolgens maatregelen genomen worden om dit 
aantal terug te dringen. In dit hoofdstuk worden een aantal maatregelen voor de beheersing of bestrijding van PPN kort beschreven (een overzicht is ook gegeven in Van der Putten et al. 2006).

\subsubsection{Graslandmanagement}

De opbrengstderving als gevolg van aantasting door PPN kan relatief en absoluut groter zijn bij ongunstige groeiomstandigheden voor het gras. Bij hetzelfde absolute schadeniveau is de relatieve schade groter als het gewas slecht groeit en daardoor een lagere opbrengst heeft (Paragraaf 3.3.4). Daarnaast kan de gevolgschade groter zijn als het gewas stress heeft en daardoor gevoeliger is voor vocht- of nutriëntengebrek en voor aantasting door andere pathogenen, (Paragraaf 3.3.4). Zorgvuldig graslandmanagement is daarom waarschijnlijk de belangrijkste maatregel om relatieve en absolute schade door PPN te verminderen. Zorgvuldig graslandmanagement richt zich op het voorkomen of verminderen van stress voor het wortelstelsel. Algemene maatregelen om dat te realiseren zijn voldoende en tijdig bekalken (voorkomen van verzuring), het optimaliseren van de ontwatering en afwatering (verminderen van vernatting en daaruit voortvloeiende kans op bodemverdichting), het verminderen van de bodemdruk (verminderen van bodemverdichting), het optimaliseren van de vochtbeschikbaarheid (verminderen vochttekort) en voldoende bemesten (voorkomen van nutriëntentekort). Een specifieke maatregel is het verlagen van de maai- of weidefrequentie. Hierdoor neemt de graswortelmassa toe (Ennik en Baan Hofman 1987) waardoor het gras minder gevoelig wordt voor wortelstress, vooral in de periode direct na oogst.

\subsubsection{Organische mest}

Een actieve bestrijding van PPN kan relatief eenvoudig gerealiseerd worden door het toedienen van organische mest. De toediening van organische stof met de mest aan de bodem stimuleert de activiteit van het bodemvoedselweb, waardoor de algehele ziekteonderdrukking en de activiteit van antagonistische schimmels toeneemt (Van der Putten et al. 2006). Hierdoor kan het aantal herbivore nematoden (waaronder PPN) afnemen, terwijl de aantallen in andere voedselgroepen toenemen (Renčo en Kováčik 2012). Het grootste effect wordt bereikt door toediening van organisch materiaal met een relatief lage C:N-verhouding en hoog eiwit/aminegehalte (Van der Putten et al. 2006). Oostenbrink (1954) geeft een vroeg voorbeeld van de bestrijding van PPN met organische mest. Bemesting met stalmest bleek in een veldproef het aantal PPN in het jaar van toediening duidelijk te verlagen, vooral de aantallen Pratylenchus pratensis en Meloidogyne hapla. Het onderdrukkende effect was ook het volgende jaar nog aanwezig en resulteerde in een hogere opbrengst van een toetsgewas gerst.

\subsubsection{Vruchtwisseling}

Vruchtwisseling is een bekende en effectieve maatregel om de opbouw van te grote aantallen PPN te voorkomen. Het principe hierbij is dat de teelt van waardplanten tijdig afgewisseld wordt met de teelt van niet-waardplanten (Van der Putten et al. 2006). Op het melkveebedrijf kan grasland (hoofdgewas) afgewisseld worden met de teelt van snijmaïs (tweede hoofgewas) of andere voedergewassen. Echter, een overstap van blijvend grasland naar vruchtwisseling is een relatief grote stap met meerdere consequenties. Daarnaast is deze maatregel op grondsoorten veen en zware klei slechts beperkt of niet mogelijk. Vruchtwisseling is ook een minder geschikte maatregel als de nematodensoort die problemen veroorzaakt een brede waardplantenreeks heeft. Engels raaigras en snijmaïs zijn allebei grasachtigen (familie Gramineae) waardoor ze voor een aantal soorten PPN allebei waardplant zijn. Als deze soorten de problemen in grasland veroorzaken, is vruchtwisseling van gras met snijmaïs weinig zinvol. Er zijn dan andere maatregelen nodig om deze soorten te bestrijden.

\subsubsection{Chemische bestrijding}

In de akkerbouw was chemische grondontsmetting lange tijd de meest toegepaste maatregel om PPN te bestrijden. In productiegrasland werd chemische ontsmetting weinig toegepast; de kosten waren relatief hoog en wogen meestal niet op tegen de economische meeropbrengst. Daarnaast werd schade door PPN vaak niet onderkend of niet belangrijk genoeg gevonden. De meeste chemische grondontsmettingsmiddelen zijn momenteel niet meer toegestaan voor gebruik, door hun 
neveneffecten op niet-doelorganismen en het bredere milieu. In de akkerbouw worden daarom soms niet-chemische bestrijdingsmethoden toegepast in teelten met een relatief hoge economische waarde. Dergelijke maatregelen bestaan uit het toepassen van zwarte braak (een tijd lang geen gewassen verbouwen), het tijdelijk onder water zetten van percelen, of de tussenteelt van Tagetes (tegen Pratylenchus spp.) Deze bestrijdingsmethoden zijn voor grasland niet aantrekkelijk, niet alleen door de relatief hoge kosten en bijkomende nadelen, maar ook door de beschikbaarheid van eenvoudigere en goedkopere maatregelen (Paragraaf 3.6.2, 3.6.3).

\subsubsection{Resistente of tolerante grasrassen}

Schade door PPN kan voorkomen of verminderd worden door het gebruik van resistente of tolerante grasrassen. Bij resistentie kunnen nematoden zich niet of minder vermeerderen en bij tolerantie heeft een gewas bij gelijke aantasting minder schade. Resistentie en tolerantie zijn twee losse raseigenschappen die in elke combinatie kunnen voorkomen. De ontwikkeling en het gebruik van resistente of tolerante rassen is een belangrijke maatregel om schade door nematoden te verminderen en is daarom in een aantal landen een veredelingsdoel (Mercer et al. 1999). In Nederland en Europa zijn geen resistente of tolerante rassen van Engels raaigras beschikbaar en zijn resistentie en tolerantie ook weinig onderzocht (Den Toom et al. 1988b; York en Cook 1989). Bij de raseigenschap resistentie is het van belang om op te merken dat deze doorbroken kan worden door een interactie van PPN met bodemschimmels (Paragraaf 3.3.3). Hierdoor kan resistentie tegen PPN onder veldomstandigheden minder zijn dan in pot- of veldproeven waarin deze bodemschimmels geen rol van betekenis speelden. Elkins et al. (1979) concludeerden dat de opbrengstderving door aantasting met PPN kleiner was voor grasgenotypen met meer en dunnere wortels, en stelde op basis daarvan dat worteleigenschappen meegenomen zouden moeten worden bij de veredeling op tolerantie. 


\section{$4 \quad$ Reflectie \& aanbevelingen}

De voorliggende studie laat zien dat PPN een behoorlijke schade in productiegrasland kunnen veroorzaken. Voor heel Nederland kan een directe economische schade berekend worden van jaarlijks $€ 200$ miljoen, bij een gemiddelde opbrengstderving van $1160 \mathrm{~kg} \mathrm{DS}^{-1}$, een oppervlakte productiegrasland van 928.000 ha (in 2017, CBS 2018) en een voederwaarde per kg DS van €0,186 (Blanken et al. 2017). De schade door PPN aan productiegrasland is daarmee economisch relevant.

Het gemiddelde niveau van opbrengstderving is geschat met gegevens uit de periode 1950 tot 1980 . Sindsdien zijn er veel veranderingen (c.q. verbeteringen) in het graslandmanagement geweest en is ook de gemiddelde opbrengst toegenomen. Daardoor zijn de bovenstaande gegevens waarschijnlijk niet meer actueel en dient het actuele niveau van opbrengstderving opnieuw vastgesteld te worden. Hiervoor is nieuw schadeonderzoek nodig.

De praktijkopbrengst van Nederlands grasland is gemiddeld $25 \%$ of 3,5 ton DS ha-1 jaar ${ }^{-1}$ lager dan de potentieel haalbare (watergelimiteerde) opbrengst (Schils et al. 2018). Een deel van deze 'yield gap' kan mogelijk verklaard worden door de opbrengstderving als gevolg van aantasting door PPN. Hiervoor is het nodig om vast te stellen wat het actuele niveau van opbrengstderving is.

Aantasting van kiemplantjes door PPN kan de (her)inzaai van grasland volledig doen mislukken. In de praktijk mislukt de herinzaai regelmatig, zonder dat hiervoor een duidelijke oorzaak aangewezen kan worden. Aantasting door PPN zou in dat geval de oorzaak kunnen zijn en het verdient daarom aanbeveling nader onderzoek te doen naar de rol van PPN bij het mislukken van herinzaai.

Een belangrijk positief effect van PPN, het stimuleren van nutriëntenmineralisatie, weegt voor voor productiegrasland niet op tegen de veroorzaakte schade. Een ander mogelijk voordeel van PPN, het stimuleren van biodiversiteit, is in productiegrasland ongewenst. Het verdient daarom aanbeveling om de aantallen PPN in productiegrasland laag te houden. In de Nederlandse melkveehouderij wordt op grasland jaarlijks 50 tot 60 ton ha-1 runderdrijfmest toegediend, verdeeld in twee tot drie giften over het groeiseizoen. Deze structurele toediening van organische mest, met een lage C:N-verhouding, geeft waarschijnlijk een structurele bestrijding van PPN, waardoor hun aantallen en schade beperkt blijven. Het is mogelijk dat door een toename van organische bemesting op grasland het actuele niveau van opbrengstderving door PPN lager is dan in het verleden.

Het in dit rapport opgenomen overzicht van vaak aangetroffen soorten nematoden in productiegrasland kan verouderd zijn. Het is niet bekend welke soorten PPN in welke aantallen momenteel in productiegrasland aanwezig zijn. Daardoor is ook niet duidelijk welke soort(en) waarschijnlijk het meest bijdragen aan een opbrengstderving. Een eerste stap om dit inzicht te verkrijgen is het uitvoeren van een nationale kartering van herbivore nematoden in productiegrasland. Een dergelijke kartering is in Nederland niet eerder uitgevoerd.

Wel zijn door het RIVM (Bilthoven) in de periode 1993 t/m 2014 algemene karteringen gemaakt van de verspreiding van bodemorganismen in Nederland, waaronder de herbivore nematoden. Om een indruk te krijgen van de samenstelling van de herbivore en plantparasitaire nematodenfauna in productiegrasland worden als vervolgstap deze gegevens geanalyseerd. 


\section{Conclusies}

- $\quad$ Plantparasitaire nematoden (PPN) veroorzaken directe schade aan grasland door het aanboren en leegzuigen van wortelcellen, het binnendringen van wortelcellen, en door lekkage van sap uit de beschadigde cellen;

- De beschadiging van wortelcellen leidt tot gevolgschade door een vervormd wortelstelsel en een grotere gevoeligheid van de wortels voor aantasting door andere pathogenen, voor droogte, nutriëntengebrek, verzuring, vernatting, verdichting, en andere stressfactoren;

- Gras is als kiemplant extra gevoelig voor schade door PPN, omdat de kiemplantjes dan de enige voedselbron zijn voor de aanwezige populatie nematoden. Hierdoor kunnen veel kiemplantjes afsterven en kan de (her)inzaai volledig mislukken;

- Schade door PPN (in de vorm van opbrengstderving) is afhankelijk van het groeistadium en de groeiomstandigheden van het gras. Bij een gelijk aantal PPN kan daardoor in de ene situatie wel duidelijke schade ontstaan en in de andere niet;

- De afhankelijkheid van schade van de groeiomstandigheden maakt het moeilijk om betrouwbare schadedrempels voor PPN vast te stellen;

- Het niveau van opbrengstderving door aantasting met PPN kan met drie methoden vastgesteld worden: berekening van de voedselbehoefte van PPN, inoculatie van de grond met PPN, of ontsmetting van de grond. Ontsmetting lijkt de meest betrouwbare methode;

- De (historische) opbrengstderving kan geschat worden op gemiddeld 1,2 ton DS ha-1 of $13 \%$ van de jaarlijkse opbrengst van Nederlands productiegrasland. Op percelen met verhoogde dichtheden PPN in de bodem liep in het verleden de derving op tot $53 \%$ van de opbrengst;

- De gemiddelde opbrengstderving komt overeen met een economische schade van jaarlijks $€$ 200 miljoen voor Nederlands productiegrasland;

- $\quad$ Met de gemiddelde opbrengstderving kan mogelijk een deel van de gemiddelde 'yield gap' van Nederlands productiegrasland (3,5 ton DS ha-1 jaar $^{-1}$ ) verklaard worden;

- Vanwege veranderingen in het graslandmanagement en een toename van het gemiddelde opbrengstniveau is de geschatte gemiddelde opbrengstderving waarschijnlijk niet meer actueel. Om het actuele niveau vast te stellen is nieuw schadeonderzoek nodig;

- $\quad$ Plantparasitaire nematoden hebben ook positieve effecten; ze kunnen de mineralisatie van nutriënten stimuleren en de (bio)diversiteit van plantensoorten in de graszode bevorderen;

- $\quad$ Bij productiegrasland wegen de voordelen van PPN echter niet op tegen de nadelen. Daarom is het gewenst om de aantallen PPN in productiegrasland laag te houden;

- De (relatieve) schade door PPN kan beperkt worden door zorgvuldig graslandmanagement; hun aantal kan actief teruggedrongen worden door regelmatige organische bemesting en vruchtwisseling;

- Een nationale kartering van herbivore nematoden in productiegrasland is nodig om vast te kunnen stellen welke soorten het meeste bijdragen aan de opbrengstderving. Een dergelijke kartering zal ook inzicht geven in de bijdrage van herbivore nematoden aan de biodiversiteit. 


\section{Dankwoord}

Wij danken Leendert Molendijk (Wageningen Plant Research), Gerard Korthals (Wageningen Plant Research/NIOO), Joeke Postma (Wageningen Plant Research), en Harm Keidel (LIOS) voor hun kritische review van conceptversies van dit rapport. Wageningen Livestock Research voerde dit onderzoek uit voor het Ministerie van Landbouw, Natuur en Voedselkwaliteit, binnen het Kennisbasisproject Bodemindicatoren (KB-21-002-010). 


\section{Referenties}

Back MA, Haydock PPJ, Jenkinson P (2002) Disease complexes involving plant parasitic nematodes and soilborne pathogens. Plant Pathology 51:683-697

Bardgett RD, Cook R, Yeates GW, Denton CS (1999) The influence of nematodes on below-ground processes in grassland ecosystems. Plant and Soil 212:23-33

Bardgett RD, Wardle DA, Yeates, GW (1998) Linking above-ground and below-ground food webs: how plant responses to foliar herbivory influence soil organisms. Soil Biology \& Biochemistry 30:18671878

Bell NL, Knight KWL, Mercer CF, Shah F, Sturhan D, Aalder LT, Yeates GW, Watson RN, Marshall JW, Page GD (2006) Occurrence and distribution of Meloidogyne spp. nematodes in New Zealand. Journal of Nematology 38:261

Blanken K, de Buisonje F, Evers A, Ouweltjes W, Verkaik J, Vermeij I, Wemmenhove H (2017) KWIN 2017-2018, Handboek 33, Wageningen Livestock Research, Wageningen

Boag B (1980) Effects of temperature on rate of feeding of the plant parasitic nematodes Rotylenchus robustus, Xiphinema diversicaudatum and Hemicycliophora conida. Journal of Nematology 12:193195

Boag B, Neilson R (1996) Distribution and ecology of Rotylenchus and Pararotylenchus (Nematoda: Hoplolaimidae) in Great Britain. Nematologica 42:96-108

Bridge J, Williams TD (2002) Plant parasitic nematodes. In: Waller JM, Lenné JM, Waller SJ (eds) Plant Pathologist's Pocketbook, $3^{\text {rd }}$ edition. CABI Publishing, Wallingford, UK, pp 140-162

CBS (2018) Centraal Bureau voor de Statistiek, Den Haag

Cook R, Mizen KA, Plowright RA, York PA (1992) Observations on the incidence of plant parasitic nematodes in grassland in England and Wales. Grass and Forage Science 47:274-279

Cook R, Yeates GW (1993) Nematode pests of grassland and forage crops. In: Evans K, Trudgill DL, Webster JM (eds) Plant parasitic nematodes in temperature agriculture. CAB International, Wallingford, UK, pp 305-350

De La Lande Cremer LCN (1965) De ontwikkelingen van het T-ziekte onderzoek. Rapport van het Instituut voor Bodemvruchtbaarheid, Haren

Denton CS, Bardgett RD, Cook R, Hobbs PJ (1999) Low amounts of root herbivory positively influences the rhizosphere microbial community of a temperate grassland soil. Soil Biology \& Biochemistry 31:155-165

Den Toom AL (1988a) Influence of temperature and soil moisture on the relation between Tylenchorhynchus dubius and Lolium perenne. Netherlands Journal of Plant Pathology 94:34-44

Den Toom AL (1988b) Response of ten cultivars of Lolium perenne to the ectoparasitic nematode Tylenchorhynchus dubius. Netherlands Journal of Plant Pathology 94:105-110

Den Toom AL (1990) Simulation of the host/parasite system Lolium perenne/Tylenchorhynchus dubius. 2. The effect of $T$. dubius on L. perenne. Netherlands Journal of Plant Pathology 96:211-225

Eisenhauer N, Ackermann M, Gass S, Klierc M, Migunovad V, Nitschkee N, Ruessb L, Sabaisc ACW Weissere WW, Scheu S (2010) Nematicide impacts on nematodes and feedbacks on plant productivity in a plant diversity gradient. Acta Oecologica International Journal of Ecology 36:477483

Eissa MFM (1971) The effect of partial soil sterilization on plant parasitic nematodes and plant growth. Proefschrift Landbouwhogeschool Wageningen

Elkins CB, Haaland RL, Rodriguez-Kabana R, Hoveland CS (1979) Plant-parasitic nematode effects on water use and nutrient uptake of small- en large-rooted tall fescue genotype. Agronomy Journal 71:497-500

Ennik GC, Baan Hofman T (1977) Response of pasture grass to thionazin and other pesticides. Publication 35, Centre for Agrobiological Research (CABO), Wageningen

Ennik GC, Baan Hofman T (1987) Variation in root mass of ryegrass types and its ecological consequences. Netherlands Journal of Agricultural Science 31:325-334

Ferris H (1982) Part I. Primary consumption. The role of nematodes as primary consumers. In: Freckman DW (ed) Nematodes in soil ecosystems, University of Texas Press, Austin, USA, pp 3-13 
Fleming TR, McGowan NE, Maule AG, Fleming CC (2016) Prevalence and diversity of plant parasitic nematodes in Northern Ireland grassland and cereals, and the influence of soils and rainfall. Plant Pathology 65:1539-1550

Griffin GD, Inserra RN, Vovlas N (1984) Rangeland grasses as hosts of Meloidogyne chitwoodi. Journal of Nematology 16:399-402

Hamilton EW, Frank DA, Hinchey PM, Murray TR (2008) Defoliation induces root exudation and triggers positive rhizospheric feedbacks in a temperate grassland. Soil Biology \& Biochemistry 40:2865-2873

Hodda M, Wanless FR (1994a) Nematodes from an English chalk grassland: species distribution. Nematologica 40:116-132

Hodda M, Wanless FR (1994b) Nematodes from an English chalk grassland: population ecology. Pedobiologia 38:530-545

Hijink MJ, Kuiper K (1966) Waarnemingen over de verdeling van aaltjes in de grond. Mededelingen Rijksfaculteit Landbouw Wetenschappen Gent, België

Jones MGK, Goto DB (2011) Root-knot nematodes and giant cells. In: Jones J, Gheysen G, Fenoll C (eds) Genomics and molecular genetics of plant-nematode interactions. Springer, Germany, pp 83100

Kimpinski J, Kunelius HT, Willis CB (1984) Plant parasitic nematodes in temperate forage grass and legume species in Prince Edward Island. Canadian Journal of Plant Pathology 6:160-164

Kuiper K (1977) Introductie en vestiging van planteparasitaire aaltjes in nieuwe polders, in het bijzonder van Trichodorus teres. Proefschrift Landbouwhogeschool Wageningen

Lewis GC, Cook R, Van den Ende A (1991) Effect of agrochemicals applied at sowing on seedling emergence and herbage yield of perennial ryegrass and white clover. Grass and Forage Science 46:121-130

Maas PWT, Brinkman H (1977) Life cycle and pathogenicity of a grass cyst nematode, Heterodera mani, on perennial ryegrass in the Netherlands. Mededelingen Faculteit Landbouwwetenschappen Rijksuniversiteit Gent 42/2, pp 1541-1548

McGlohon NE, Sasser JN, Sherwood RT (1961) Investigations of plant parasitic nematodes associated with forage crops in North Carolina. Technical Bulletin North Carolina Agricultural Experiment Station 148 (referentie in Cook and Yeates 1993)

Mercer CF, Bell NL, Yeates GW (2008) Plant-parasitic nematodes on pasture in New Zealand. Australasian Plant Pathology 37:279-288

Mercer CF, Van den Bosch J, Miller KJ (1999) Effectiveness of recurrent selection of white clover (Trifolium repens) for resistance to New Zealand populations of clover cyst nematode (Heterodera trifolii). Nematology 1:449-455

Oostenbrink M (1953) Ditylenchus radicicola (Greeff, 1872) Filipjev, 1936, een wortelaaltje in het Nederlandse grasland. Tijdschrift Over Plantenziekten 59:149-152

Oostenbrink M (1954) Over de betekenis van vrijlevende wortelaaltjes in land- en tuinbouw. Verslagen en mededelingen van de Plantenziektekundige Dienst 124:196-233

Oostenbrink M (1957a) Das vorkommen von Artgemischen bei Pflanzen-parasitairen Nematode. Nematologica II, Supplement:342-346

Oostenbrink M (1957b) Nematoden in verband met de vruchtbaarheid van de grond. Veenman \& Zonen, Wageningen

Oostenbrink M (1969) Epidemiologie van aaltjes. Netherlands Journal of Plant Pathology 75:317

Perry VG, Darling HM, Thorne G (1959) Anatomy, taxonomy and control of certain spiral nematodes attacking bluegrass in Wisconsin. University of Wisconsin Research Bulletin 207, Madison, USA

Poll J, Marhan S, Haase S, Hallmann J, Kandeler E, Ruess L (2007) Low amounts of herbivory by rootknot nematodes affect microbial community dynamics and carbon allocation in the rhizosphere. FEMS Microbiology Ecology 62:268-279

Radice AD (1985) Studies on the host range, biology, and pathogenicity of Punctodera punctata infecting turfgrasses. Journal of Nematology 17:162-165

Renčo M, Kováčik P (2012) Response of plant parasitic nematodes and free living soil nematodes to composted animal manure soil amendments. Journal of Nematology 44:329-336

Roberts H, Cotten J (1979) Effect of Xiphinema diversicaudatum on the growth of four seedling grasses. Plant Pathology 28:61-67 
Schils RLM, Höglind M, Van Middelkoop J, Holshof G, Verloop JJ, Rijk B, Van de Ven G, Van den Berg W, Van der Schoot JR, Van Ittersum MK (2018) Framework for yield gap analysis in grasslands. Grassland Science in Europe 23:90-92

Schoening C, Wurst S (2016) Positive effects of root-knot nematodes (Meloidogyne incognita) on nitrogen availability do not outweigh their negative effects on fitness in Nicotiana attenuata. Plant and Soil 400:381-390

Scott JA (1979) An ecosystem-level trophic-group arthropod and nematode bioenergetics model. In: French NR (ed) Perspective in grassland ecology: Ecological studies, Volume 32. Springer, New York, USA, pp 107-116

Seinhorst JW, Kozlowska J (1979) Longidorus elongatus and Tylenchorhynchus dubius on Lolium perenne. Nematologica 25:313-321

Simons WR (1973) Nematode survival in relation to soil moisture. Proefschrift Landbouwhogeschool Wageningen

Sohlenius B, Bostrom S, Viketoft M (2011) Effects of plant species and plant diversity on soil nematodes - a field experiment on grassland run for seven years. Nematology 13:115-131

Spaull AM, Mewton PG, Clements RO (1985) Establishment and yield of 3 ryegrasses following aldicarb use, and changes in abundance of plant parasitic nematodes. Annals of Applied Biology 106:313-321

Sturhan D (1982) Distribution of cereal and grass cyst nematodes in the Federal Republic of Germany. European Plant Protection Organisation Bulletin 12:321-324

Thies JA, Petersen AD, Barnes DK (1995) Host suitability of forage grasses and legumes for root-lesion nematode Pratylenchus penetrans. Crop Science 35:1647-1651

Tu C, Koenning SR, Hu S (2003) Root-parasitic nematodes enhance soil microbial activities and nitrogen mineralization. Microbial Ecology 46:134-144

Van Bezooijen J (1979) Nematodes in grasses. Mededelingen Faculteit Landbouwwetenschappen Rijksuniversiteit Gent 44, pp. 339-349

Van Bezooijen J, Murray PJ (1989) The impact of nematodes and Vydate (Oxamyl) applications on the establishment of newly sown grass. Mededelingen Faculteit Landbouwwetenschappen

Rijksuniversiteit Gent 54/3b, pp 1195-1200

Van der Putten WH, Cook R, Costa S, Davies KG, Fargette M, Freitas H, Hol WHG, Kerry BR, Maher N, Mateille T, Moens M, De la Peña E, Piśkiewicz AM, Raeymaekers ADW, Rodríguez-Echeverrí S, Van der Wurff AWG (2006) Nematode interactions in nature: models for sustainable control of nematode pests of crop plants? Advances in Agronomy 89:227-260

Van der Putten WH, Peters BAM (1997) How soil-borne pathogens may affect plant competition. Ecology 78:1785-1795

Verschoor BC, De Goede RGM (2000) The nematode extraction efficiency of the Oostenbrink elutriator: cottonwool filter method with special reference to nematode body size and life strategy. Nematology 2:325-342

Verschoor BC (2002) Carbon and nitrogen budgets of plant-feeding nematodes in grasslands of different productivity. Applied Soil Ecology 20:15-25

Verschoor BC, De Goede RGM, De Hoop JW, De Vries FW (2001) Seasonal dynamics and vertical distribution of plant-feeding nematode communities in grasslands. Pedobiologia 45:213-233

Verschoor BC, Pronk TE, De Goede RGM, Brussaard L (2002) Could plant-feeding nematodes affect the competition between grass species during succession in grasslands under restoration management? Journal of Ecology 90:753-761

Viketoft M, Sohlenius B, Bostrom S, Palmborg C, Bengtsson J, Berg MP, Huss-Danell K (2011) Temporal dynamics of soil nematode communities in a grassland plant diversity experiment. Soil Biology \& Biochemistry 43:1063-1070

Wasilewska L (1995) Differences in development of soil nematode communities in single- and multispecies grass experimental treatments. Applied Soil Ecology 2:53-64

Watson RN, Yeates GW, Littler RA, Steele KW (1985) Responses in nitrogen fixation and herbage production following pesticide application on temperate pastures. In: Chapman RB (ed) Proceedings of the $4^{\text {th }}$ Australasian Conference on Grassland Invertebrate Ecology. Australasian Plant Protection Society, Canterbury, New-Zealand, pp 103-113

Wetzel T (1969) Untersuchungen über den wandernden Wurzelnematoden Pratylenchus neglectus an Futtergräsern. Nematologica 15:193-200

Widdowson JP, Yeates GW, Healy WB (1973) The effect of root nematodes on the utilisation 
of phosphorus by white clover on a yellow-brown loam. New Zealand Journal of Agricultural Research 16:77-80

Woldring JJ (1972) Het effect van maatregelen tegen het aaltje Trichodorus teres in grasland. Rapport 9, Proefstation voor de Rundveehouderij, Lelystad

Yeates GW (1974) Effects of Heterodera trifolii on growth of clover in a yellow-grey earth under greenhouse conditions. New Zealand Journal of Agricultural Research 17:379-385

Yeates GW (1977) Soil nematodes in New Zealand pastures. Soil Science 123:415-422

Yeates GW, Bardgett RD, Cook R, Hobbs PJ, Bowling PJ, Potter JF (1997) Faunal and microbial diversity in three Welsh grassland soils under conventional and organic management regimes. Journal of Applied Ecology 34:453-470

Yeates GW, Bardgett RD, Mercer CF, Saggar S, Feltham CW (1999) The impact of feeding by five nematodes on ${ }^{14} \mathrm{C}$ distribution in soil microbial biomass and nematodes: initial observations. New Zealand Journal of Zoology 26:87

Yeates GW, Bongers T, De Goede RGM, Freckman DW, Georgieva SS (1993) Feeding habits in soil nematode families and genera - An outline for soil ecologists. Journal of Nematology 25:315-331 Yeates GW, Crouchley GC, Witchalls JT (1975) Effect of soil fumigation on white clover growth in a yellow-grey earth infested with clover cyst nematode. New Zealand Journal of Agricultural Research 18:149-153

York PA, Cook R (1989) Variation in forage grasses as hosts of the root-knot nematode Meloidogyne naasi (Franklin) and selection for resistance in ryegrass. Euphytica 43:135-141 


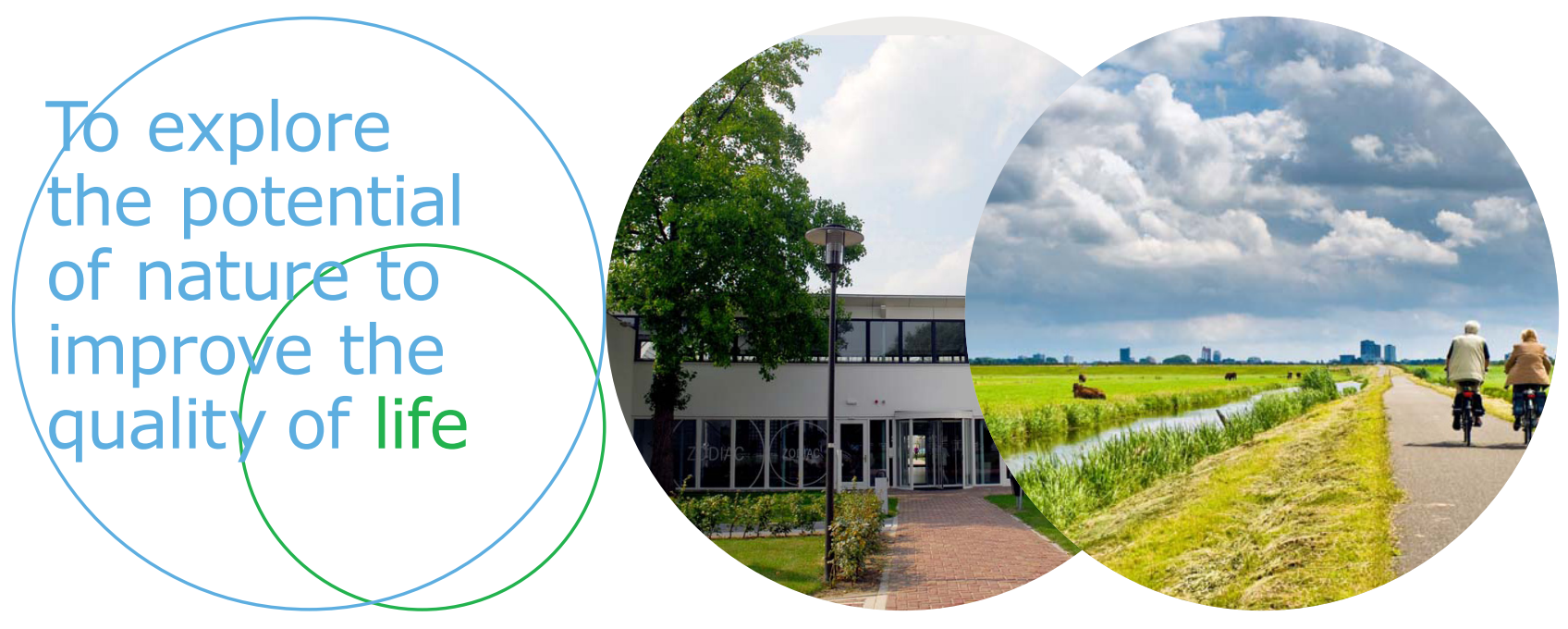

Wageningen Livestock Research Postbus 338

Wageningen Livestock Research ontwikkelt kennis voor een zorgvuldige en $6700 \mathrm{AH}$ Wageningen

T 0317483953

renderende veehouderij, vertaalt deze naar praktijkgerichte oplossingen en innovaties, en zorgt voor doorstroming van deze kennis. Onze wetenschappelijke E info.livestockresearch@wur.nl www.wur.nl/ livestock-research kennis op het gebied van veehouderijsystemen en van voeding, genetica, welzijn en milieu-impact van landbouwhuisdieren integreren we, samen met onze klanten, tot veehouderijconcepten voor de $21 \mathrm{e}$ eeuw.

De missie van Wageningen University \& Research is 'To explore the potential of nature to improve the quality of life'. Binnen Wageningen University \& Research bundelen 9 gespecialiseerde onderzoeksinstituten van Stichting Wageningen Research en Wageningen University hun krachten om bij te dragen aan de oplossing van belangrijke vragen in het domein van gezonde voeding en leefomgeving. Met ongeveer 30 vestigingen, 6.500 medewerkers en 10.000 studenten behoort Wageningen University \& Research wereldwijd tot de aansprekende kennisinstellingen binnen haar domein. De integrale benadering van de vraagstukken en de samenwerking tussen verschillende disciplines vormen het hart van de unieke Wageningen aanpak. 